\title{
Assessing Wetland Condition with GIS: \\ A Landscape Integrity Model for Montana
}

\author{
Prepared for: \\ The Montana Department of Environmental Quality and \\ The Environmental Protection Agency \\ Prepared by: \\ Linda K. Vance \\ Montana Natural Heritage Program \\ a cooperative program of the \\ Montana State Library and the University of Montana
}

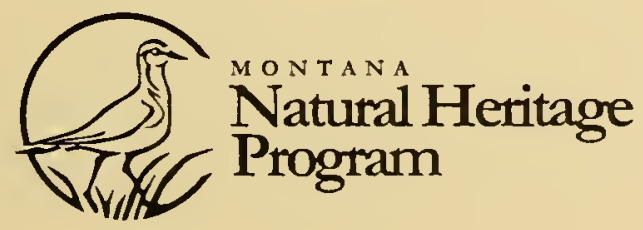




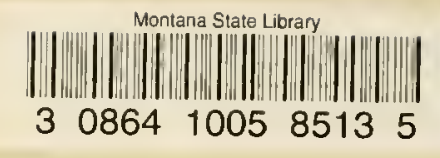




\section{Assessing Wetland Condition with GIS: A Landscape Integrity Model for Montana}

Prepared for:

The Montana Department of Environmental Quality and

The Environmental Protection Agency

Agreement Number:

CD-978744-01

Prepared by:

Linda K. Vance
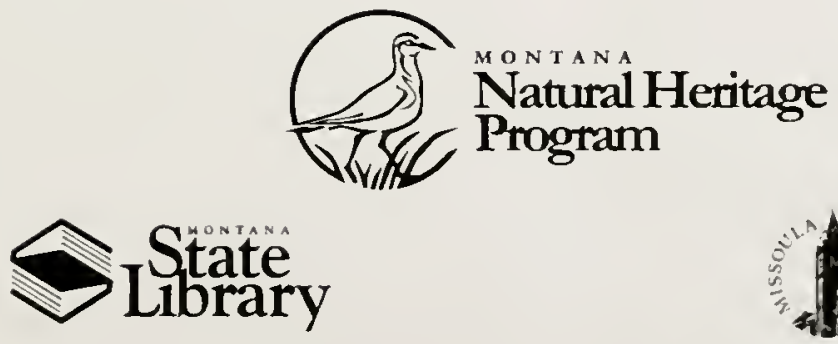

Montana

(C) 2009 Montana Natural Heritage Program

P.O. Box 201800 • 1515 East Sixth Avenue • Helena, MT 59620-1800 406-444-5354 
This document should be cited as follows:

Vance, Linda K. 2009. Assessing Wetland Condition with GIS: A Landscape Integrity Model for Montana. A Report to The Montana Department of Environmental Quality and The Environmental Protection Agency. Montana Natural Heritage Program, Helena, MT. 23 pp. plus appendices. 


\section{Executive Summary}

Wetlands are increasingly at risk from human alteration of the landscape. Although site-specific activities like dredging, ditching, filling, draining, and plowing have the most direct and obvious impacts on wetland integrity, activities within the surrounding catchment can also lead to degradation by changing wetland hydrologic function, increasing nutrient and sediment loads, and providing a conduit for the spread of invasive and exotic species. With the widespread adoption of GIS technology, it has become possible to characterize large landscapes and identify potential stressors from existing datasets. Because so much information is available on a desktop computer, the U.S. Environmental Protection Agency advocates the use of GIS-based landscape analysis to provide a preliminary assessment of wetland condition in a project area (Level I), before conducting field-based rapid (Level II) and intensive (Level III) assessments.

Although most Level I assessment approaches are developed with best professional judgment, when field data is available, it can support development, calibration and validation of metrics. In Montana, while we do not have a wetland condition dataset providing detailed, specific measures of hydrologic, physical, and biotic parameters, we do have rapid assessment data on over a thousand wetlands across the state. Our goal in this study was to determine whether we could use this data to identify landscape-level metrics with a good ability to predict wetland condition, or, at the least, to calibrate and validate a best professional judgment-based tool.

From a review of the literature, we identified a number of landscape-scale metrics that are widely believed to influence wetland condition. We calculated values for these metrics in several different buffer distances for a random sample of 591 wetlands. We ran an ANOVA to determine the metrics that had significant relationships to the field-determined overall condition scores. Each significant metric was further examined through a linear regression to determine the strength of the relationship. Metrics were also combined and analyzed in multiple stepwise regression routines to evaluate interactions, and assessed with CART (Classification and Regression Tree) analysis.

At the 6th code Hydrologic unit (HUC), 1 kilometer, 500 meter, and 200 meter buffer distance, the combined metrics of percent forest cover, road density, and number of stream road crossings had the strongest predictive value for overall score. However, the R-squared value for the three metrics combined was only 0.14 at the 6 th code HUC level. When measured at the buffer level, the combination of metrics had an even lower R-squared value. At 1,000 meters, the R-squared value dropped to 0.13 , at 500 meters it was 0.11 , and at 200 meters, the $R$-squared value was 0.09 , and road density was no longer significantly correlated with overall score. We had observed that there was a strong ecoregional skew in the condition scores, with wetlands in mountain ecoregions having a higher average score than wetlands in plains ecoregions ( 0.93 vs. 0.77 on a scale of 0.0 to 1.0). Therefore, we split the assessment data into a mountain and a plains subsets and reran the analysis. With the data divided, percent forest was no longer significant at any scale. For wetlands in the mountain ecoregions ( $n=262)$, road density was the only metric that was significant at all levels, although the R-squared value was never higher than 0.07 . In the 1 kilometer buffer, the percentage of crop agriculture was also significant, although it had no significance at other buffer distances. In the plains ecoregions, no metrics were significant at 200 meters. Percent natural 
grassland and road density within 500 meters were both significantly correlated with overall score but had very low R-squared value ( 0.02 and 0.01 , respectively). At the 1,000 meter buffer scale, only the number of stream road crossings was significant. No metric was significantly correlated to overall wetland condition when measured at the 6th code HUC level in either the mountain dataset or the plains dataset. When we added an environmental variable (relative effective annual precipitation) to the analysis, we found it had high predictive value for the dataset as a whole, and within the subset of mountain ecoregions. In the plains, where it varied less, it was not significant.

Using best professional judgment, we then built a Montana Landscape Integrity Model (MT-LIM) and used the dataset to calibrate it. An additional 100 points drawn from the initial dataset and 180 points assessed specifically for this study were used in validation. The model is an inverse weighted distance model premised on the idea that ecosystem processes and functions achieve their fullest expression in areas where human activities have the least impact. In the case of wetlands, it presumes that wetland condition will be poorest in close proximity to roads, commercial or industrial development, urban areas, resource extraction sites, or hydrologic modifications. The model is built into a single raster layer covering the entire state. The raster pixel size is 30 meters by 30 meters, or 900 square meters. Pixel values range from 100 to 745 .

The model was used to calculate a mean landscape integrity score for pixels within 100 meters of a wetland. This score was combined with a relative effective precipitation value from the assessment point, and wetlands were assigned to an ordinal condition class (A, B, C or $\mathrm{D})$ using thresholds we identified through calibration. When compared to the condition classes assessed in the field using rapid assessment methods, this approach accurately predicted the measured condition in $50-55 \%$ of cases, depending on field method. In mountain ecoregions, it accurately predicted A-ranked wetlands in $75 \%$ of the cases. Sixty-five percent of the plains wetlands and $83.5 \%$ of the mountain wetlands were classified acceptably, i.e., the classifications were either accurate or no more than one rank higher than what was assigned in the field.

This study demonstrated the potential of landscape-level metrics and models to predict wetland condition using remotely-sensed data in Montana. At the same time, it showed that environmental variables and site-specific activities may be far more important drivers of wetland condition than land uses occurring at a broader scale. Human disturbances can affect wetlands at multiple scales, and because they tend to interact both with each other and with environmental variables, it is exceedingly difficult to quantify or predict their effects. UItimately, landscape-level wetland assessment may never be a satisfactory substitute for field assessments. Nonetheless, when field assessments are not practical, landscape-level assessment is the only alternative. With completion of the Landscape Integrity Model and an approach for integrating it with precipitation data, we now have a tool offering a quick and efficient way to begin that task. 


\section{ACKNOWLEDGements}

This project was funded by an EPA Region 8 Wetland Program Development Grant, administered by the Montana Department of Environmental Quality. Thanks are due to Lynda Saul of MT DEQ and Jill Minter and Toney Ott of EPA Region 8 for their support, and for their commitment to advancing wetland science in the Rocky Mountain West.

The work benefited from the input of many GIS analysts and wetland scientists. Jane Horton. now of Montana Fish, Wildlife and Parks, helped with an initial version of the analysis. Catherine Maynard of the NRCS provided insight and recommendations through the course of the project. Members of the Western Wetland Monitoring and Assessment Workgroup, notably Rebecca Phillips, Ofer Beeri, and Dath Mita, shared their own experience with Level I wetland assessment approaches. Don FaberLangendoen of Natureserve. Joanna Lemly of the Colorado Natural Heritage Program and
Joe Rocchio of the Washington Department of Ecology offered ideas based on their extensive field observations of landscape-level wetland impacts. Cat McIntyre of the MTNHP gave me helpful suggestions drawn from her own work with landscape stressors and amphibian distribution.

Early versions of this project were presented at the Intermountain GIS Conference, the Western Wetland Monitoring and Assessment Workgroup Conference, and the Natureserve Western Heritage Conference. Thanks to the many conference participants who asked helpful questions and offered suggestions.

Finally, thanks are due to Karen Newlon of the MTNHP for her editorial review, and to Coburn Currier of MTNHP for his work formatting and editing the final version. Any errors that remain are mine alone. 


\section{Table of Contents}

Introduction

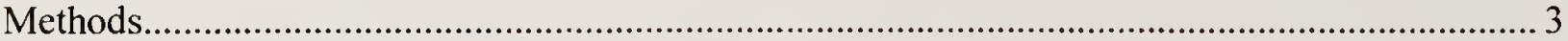

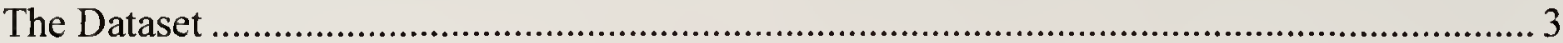

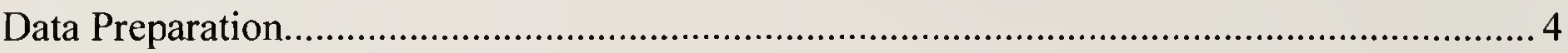

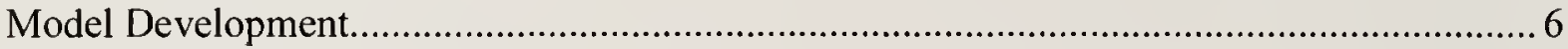

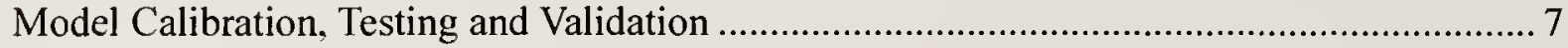

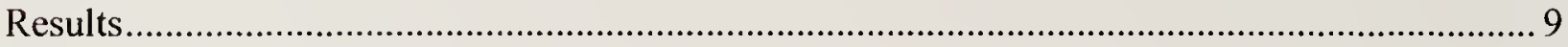

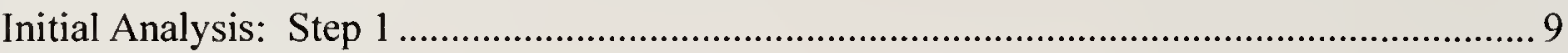

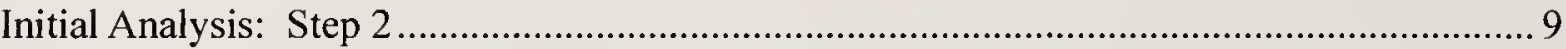

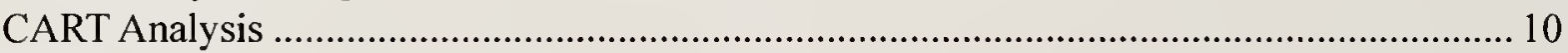

The Montana Landscape Integrity Model ..................................................................... 10

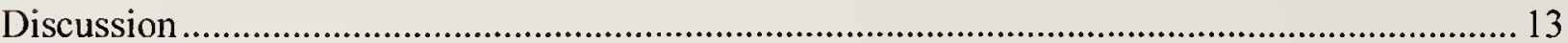

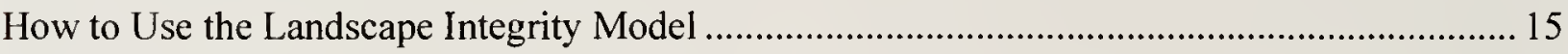

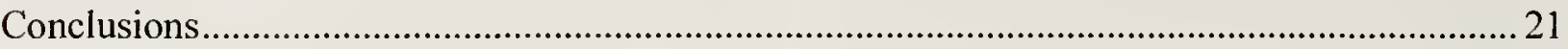

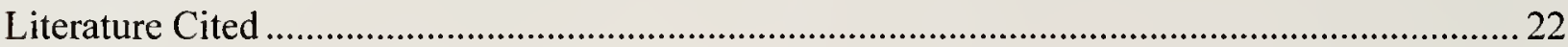

Appendix A: MTDEQ Rapid Assessment Form

Appendix B: Development of the Montana Landscape Integrity Model

Appendix C: Ecological Integrity Assessment Form

\section{List OF Figures}

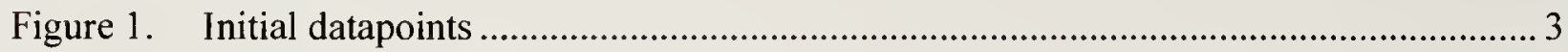

Figure 2. Wetland within high-integrity landscape ................................................................ 11

Figure 3. Wetland adjacent to multiple stressors .................................................................... 11

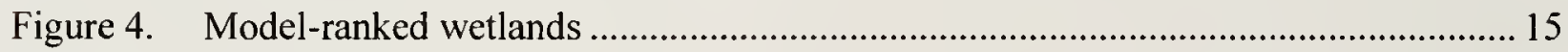

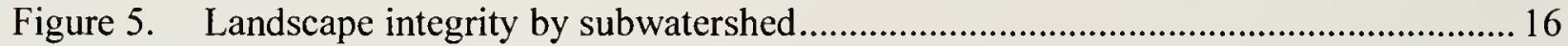

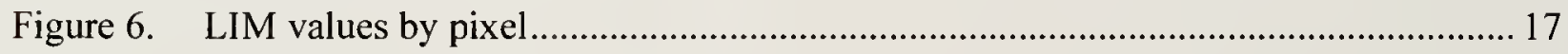

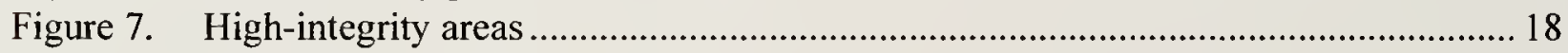

Figure 8. Northwestern Montana LIM blocks .............................................................. 19

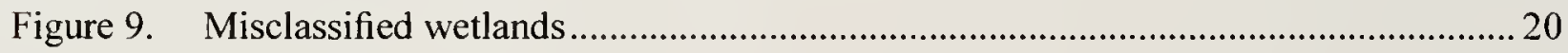

\section{LIST OF TABLES}

Table 1. National Land Cover Dataset (2001) cover classes................................................... 1

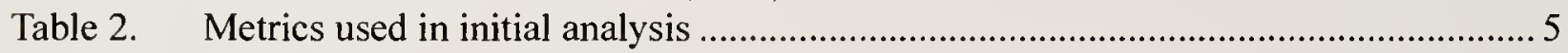

Table 3. GIS data sources used in this report ................................................................. 7 


\section{INTRODUCTION}

Wetlands are increasingly at risk from human alteration of the landscape (Allan 2004, Hychka et al. 2007). While site-specific activities like dredging. ditching, filling, draining, and plowing are the most obvious examples, alterations that occur within the surrounding catchment can negatively impact wetlands by changing wetland hydrologic function (Gregory et al. 1991), increasing nutrient and sediment loads (Skagen et al. 2008), and providing a conduit for the spread of invasive and exotic species (Magee and Kentula 2005). Consequently, most wetland assessment protocols incorporate metrics that attempt to capture the effects of landscape-level impacts, typically by measuring the extent and condition of the surrounding buffer or by including a checklist of stressors occurring in the nearby landscape (Faber-Langendoen et al. 2008).

With the widespread adoption of GIS technology, it has become possible to characterize large landscapes and identify potential stressors from existing datasets (LaGory and Kuiper 2004, Phillips et al. 2005). The USGS National Land Cover Dataset (NLCD), derived from 30-meter Landsat TM imagery, classifies land cover and land use into 16 categories (Table I), allowing rapid evaluation of the proximity of target wetlands to known disturbances like agriculture and urban development. By combining land cover data with similar datasets that identify and depict roads, water features, and topography, researchers have produced synoptic maps that broadly predict wetland impairment (Brooks et al. 2004). This success has contributed to the growing popularity of a three-tiered approach to wetland assessment (Kentula 2007). In this approach, readily available GIS datasets are used to create an initial characterization of wetland condition based on landscape-level indicators (Level I). A subset of wetlands assessed at Level I can then be further evaluated in the field using rapid assessment protocols (Level II), and a subset of those can be subjected to intensive assessments using metrics of floristic quality, soil status, hydrology, and/or biotic richness (Level III). If Level III metrics and scoring thresholds have been derived from
Table 1. National Land Cover Dataset (2001) cover classes.

\begin{tabular}{|rl|}
\hline CODE & CLASS \\
11 & Open water \\
12 & Perennial ice or snow \\
21 & Developed, open space \\
22 & Developed, low intensity \\
23 & Developed, medium intensity \\
24 & Developed, high intensity \\
31 & Barren land \\
41 & Deciduous forest \\
42 & Evergreen forest \\
43 & Mixed forest \\
52 & Scrub/shrub \\
71 & Grassland/herbaceous \\
81 & Pasture/Hay \\
82 & Cultivated crops \\
90 & Woody wetlands \\
95 & Emergent herbaceous wetlands \\
\hline
\end{tabular}

measured parameters in wetlands of known condition, then scores from a Level III assessment can be used to validate and calibrate the other assessment levels (Hychka et al. 2007). In the absence of these scores or data, a more general Level I tool can be crafted using indicators derived from best professional judgment (Brooks et al. 2004) or from indicators that have been used successfully in other states (Mack 2007).

However, existing Level I approaches may not be easily applied to Montana. For the most part, these tools were initially developed in the eastern U.S., where natural landscapes are more homogenous. In Pennsylvania, for example, percent natural forest within a wetland buffer is a good indicator of wetland disturbance, because the presettlement norm was continuous forest; the absence of forest is, by definition, a sign that the landscape has been altered (Brooks et al. 2004, Hychka et al. 2007). In Montana, by contrast, there is no single presettlement vegetation class, and in the case of some classes such as grassland and shrubland, human disturbances typically manifest 
as changes in condition and quality, rather than in fragmentation and patchiness. Metrics based on agriculture present similar problems. In the Great Lakes region, where agricultural development has been found to have measurable effects on wetland condition (Brazner et al. 2007), agriculture is mostly crop-based, and is discernible even by the naked eye on satellite imagery. In western rangelands, where most of our agricultural areas are devoted to free-ranging livestock rather than crops, it is much more difficult to pinpoint concentrated impacts without intensive image analysis and post-processing. Neither the NLCD nor the more detailed ReGAP vegetation maps distinguish rangeland land use from herbaceous land cover. Consequently, areas with heavy livestock use and areas where livestock are absent or excluded are both classified as "grassland/herbaceous," generally considered to be a "natural" land cover class in Level I assessments. Moreover, even if we could identify rangelands with heavy current grazing pressure, we would not necessarily identify all areas affected by grazing. Many landscape-level grazing impacts, such as loss of riparian vegetation and downcutting or entrenchment of streams, have occurred in the past and persist even in the absence of livestock. Finally, in rural states like Montana, with its large land area and small population footprint, the assumptions of Level I assessments may not apply. For example, road proximity or road density is typically assumed to be a stressor on wetlands. However, the effect of these presumed stressors is probably very different in a state where over a hundred thousand vehicles travel a highway each day and in a state where a highway may support less than a thousand vehicles a day. Because of lower levels of intensity, landscapelevel factors may not have the same impacts on wetland condition in rural states as in urban ones, and may generally be less significant than direct, site-specific factors like plowing, excavation, and damming, or natural stressors like drought.

Nevertheless, Level I assessment tools hold great appeal in Montana, where the size and diversity of the landscape are such that even probabilistic, rapid assessments will take years to execute on a statewide basis. If the assumption that landscapelevel stressors compromise wetland integrity is correct, then Level I assessments could be used to identify areas where these stressors are at play, thereby helping resource managers identify areas where more detailed monitoring and assessment projects should be done. Similarly, a Level I assessment tool could help delineate areas with few threats and identify where high quality wetlands, and potentially uncommon species, are likely to be found.

Therefore, we wanted to determine whether it was possible to develop a Level I assessment tool for Montana and to base it on a combination of best professional judgment, metrics derived from the literature, and field data. Although Montana is in the early stages of conducting Level III assessments across the state, the Montana Natural Heritage Program has completed over a thousand rapid assessments of wetland condition in the course of amphibian surveys using a protocol developed by the Montana Department of Environmental Quality (MTDEQ 2005). We chose these data as our starting point for determining which identifiable landscape-level stressors might be correlated with a loss of wetland condition. If we could identify these stressors, then it would be possible to build a Level I assessment tool appropriate for Montana and provide a template for other rural western states to adapt. 


\section{MeTHODS}

\section{The Dataset}

The ivetland assessment data used in the initial analysis and model calibration were collected by Montana Natural Heritage Program amphibian survey crews between 2004 and 2007. The amphibian survey sampling scheme delineates 11 geographic strata based on ecoregions and subbasins. Within those 11 strata, there are up to three land ownership strata ( $>40 \%$ public, $>40 \%$ tribal, $<40 \%$ public or tribal). In total, there are 28 "target populations" from which subwatersheds (USGS 6th code hydrologic units) can be randomly selected in numbers proportionate to the total area and number of subwatersheds in the sampling frame. Every lentic wetland in the selected subwatershed is then visited and assessed using a protocol developed by the
Montana Department of Environmental Quality (MTDEQ). This study design, while appropriate for amphibian breeding site occupancy surveys, was not entirely appropriate for our analysis, as many of the wetlands in any given subwatershed were in very close proximity to each other $(<100 \mathrm{~m})$ and were therefore subject to the same suite of stressors. To minimize autocorrelation, we overlaid a grid of public land survey sections (one mile by one mile) on the sampled subwatersheds and randomly selected one wetland assessment site per square mile section for our analysis. This selection provided 591 wetland assessments, broadly distributed across the state but relatively concentrated in less-developed areas (Figure 1). We drew another 100 assessments from the entire dataset to use for testing.

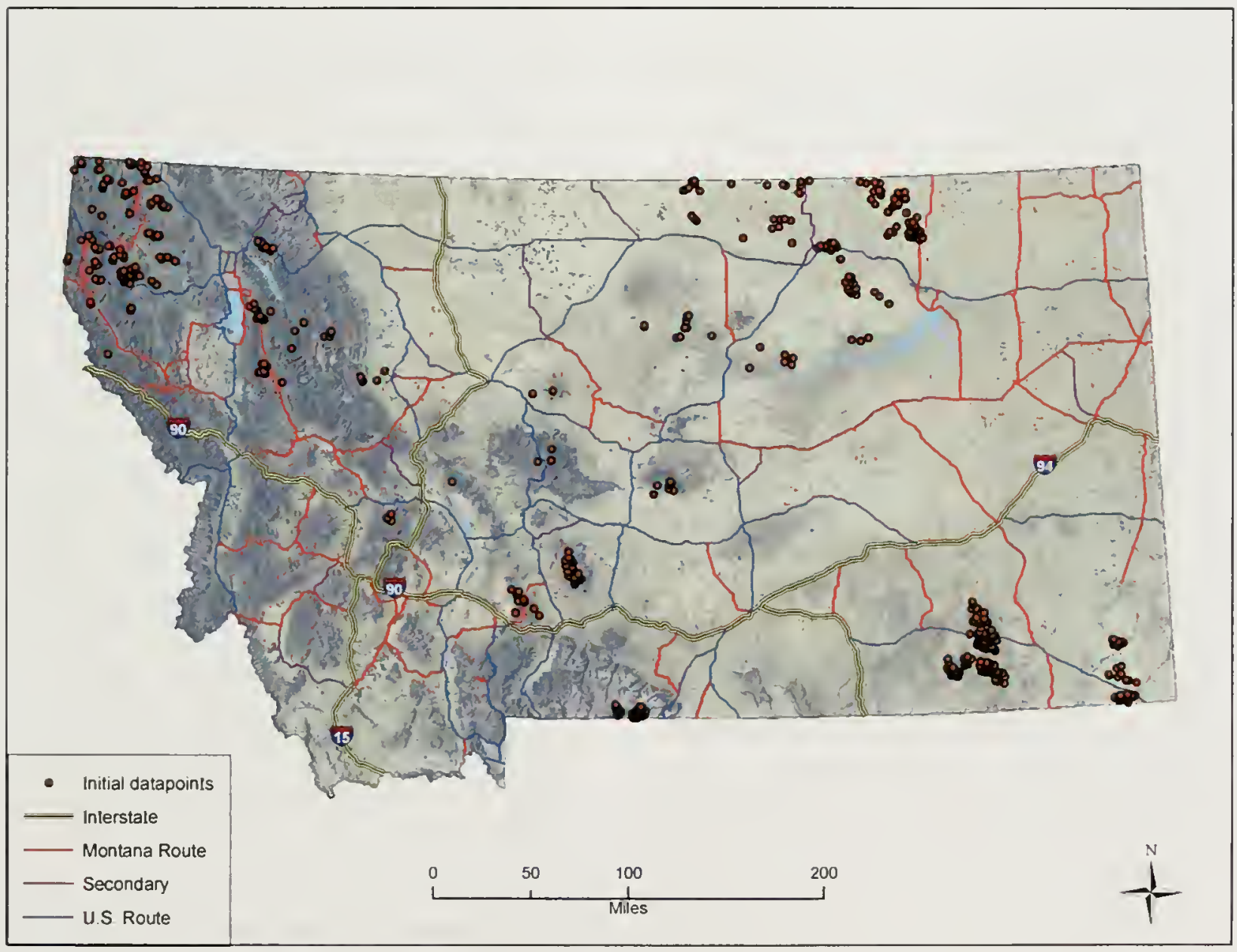

Figure 1. Initial datapoints $(n=591)$. 
The MTDEQ rapid assessment method (MTDEQ-RAM) evaluates both stressors and condition within a wetland and its 100 meter buffer. Stressors occurring between 100 and 500 meters are noted but not scored. Metrics cover hydrogeomorphology, vegetation, buffer condition, and water quality (Appendix A). Scores on individual metrics are combined into an overall score ranging from $0.0-1.0$. Because our goal was to build a statewide Level I tool that could identify broad condition classes, our analysis focused on the multi-metric synthesis represented by the overall score.

\section{Data Preparation}

Landscape-level stressors operate at multiple scales, and different wetland indicators react in different ways. In a review of the literature, Brazner et al. (2007) observed that stressors like row crops and pastures appear to operate at the watershed scale, while effects of urbanization are most pronounced at the site level. They also noted that response variables are not uniformly sensitive to watershed-scale versus local disturbances. For example, water quality metrics respond to watershed or regional disturbances while wetland vegetation tends to reflect more localized impacts.

There is little consistency in the scale at which Level I assessments are conducted. Mita et al. (2007) used a 300 meter buffer in the Prairie Pothole Region of central North Dakota because of the irregular, hummocky landscape. Brooks et al. (2004) used a one kilometer buffer, as do researchers using the Landscape Development Intensity Index developed by Brown and Vivas (2005; Mack 2007). Hychka et al. (2007) evaluated five spatial scales: a 100 meter buffer, a 250 meter buffer, the upstream catchment area and the intersection of the upstream catchment, and each of the two buffer circles. They concluded that the most predictive metrics were measured at a 250 meter and upstream catchment scale. Given this variability, we decided to calculate metrics at several different scales: 200 meters, 500 meters, one kilometer, and the entire 6th code HUC. To obtain the evaluation areas, we buffered each assessment point by each scale using ArcGIS 9.2 (ESRI 2006).

We were fortunate that Montana is rich in most types of GIS data. The Natural Resource Information Service, part of the Montana State Library, maintains multiple datasets and makes them freely available for downloading from the Montana GIS Portal'. Many of these digital datasets have been derived from national datasets (e.g., the National Land Cover Dataset, the National Hydrography Dataset, the TIGER roads data, the National Elevation Dataset) while others are Montana-specific products. In our initial evaluations, we used only data that were broadly available: land cover, roads, and hydrology ${ }^{2}$. Although our primary goal was to create a Level 1 tool that would serve the needs of Montana land managers and scientists, we were hopeful we could find an approach that could also be used in other Rocky Mountain states. Therefore, in the initial analysis we did not include data that might not exist in all states, such as detailed cadastral layers and oil and gas well locations.

After buffering the data points, we calculated land cover and stressor metrics for each buffer using the Analytical Tools Interface for Landscape Assessment 3.0 (ATtILA) (Ebert and Wade 2000), an EPA-developed program that runs in ArcView 3.3 (ESRI 2000) with the Spatial Analyst extension. Results were exported to ArcGIS 9.2 for further analysis and data display. We ran an ANOVA to determine the metrics that had significant relationships to the overall scores at each buffer distance. Each significant metric was further examined through a linear regression to determine the strength of the relationship. Metrics were also combined and analyzed in multiple stepwise regression routines to evaluate interactions. All analyses were performed in SYSTAT 11.2. (Systat, Inc.) Table 2 shows the calculated metrics used in this stage of the analysis.

\footnotetext{
1 http://gisportal.mt.gov/Portal/

${ }^{2}$ Unfortunately, one dataset that we would have liked to use, the National Wetlands Inventory, is not available in digital format for all of Montana, so we were unable to incorporate it into our statewide analysis.
} 
Table 2. Metrics used in initial analysis.

\begin{tabular}{|ll|}
\hline METRICS BY & UNIT OF \\
CATEGORY & MEASUREMENT \\
Land cover and land use & \\
Percent forest & percent \\
Percent grassland & percent \\
Percent shrubland & percent \\
Percent total agriculture & percent \\
Percent crop agriculture & percent \\
Percent pasture/hay & percent \\
Percent urban & percent \\
Percent natural & percent \\
Road Density & $\mathrm{km} / \mathrm{km}^{2}$ \\
Patch density and size metrics & \\
Mean forest patch Size & hectares \\
Mean grassland patch size & hectares \\
Number of forest patches & count \\
Number of grassland patches & count \\
Forest patch density & count $/ \mathrm{km}^{2}$ \\
Grassland patch density & count $/ \mathrm{km}^{2}$ \\
Hydrology metrics & \\
Percent altered streams in buffer & percent \\
Stream road crossings & count \\
Reservoir density & count $\mathrm{km}^{2}$ \\
Water rights points of use & count $/ \mathrm{km}^{2}$ \\
Population and ownership metrics & \\
Population density & count $/ \mathrm{km}^{2}$ \\
Percent public land ownership & percent \\
Percent land in managed status (wilderness. RNA. conservation easements) & percent \\
Percent land owned by timber companies & percent \\
\hline
\end{tabular}

When the initial analysis failed to yield sufficient predictors for model development, we added an environmental variable, relative effective annual precipitation (REAP), to the analysis (NRCS 2008). REAP differs from standard annual precipitation measurements in that it represents the amount of moisture available at a location, accounting for precipitation, slope, aspect, and soil properties. We used a simple least squares regression of overall score against the interpolated value for REAP at the wetland assessment point, using the entire dataset. This variable had good predictive value for modeling wetland condition, so we incorporated REAP into subsequent analyses. We then used CART (Classification and Regression Tree) analysis to further analyze data for model development. CART is a nonparametric method frequently used to explore ecological response data involving multiple predictor variables that may be interacting in ways that are difficult to model with linear approaches (Brazner et al. 2007, De'Ath and Fabricus 2000). Classification trees help to pinpoint predictor variables that maximize within-group homogeneity in a dataset. The CART analysis was performed using SYSTAT 11.2's TREE program, which uses an automatic interaction detection algorithm to find the best fit for the regression. The initial cluster of values is subjected to stepwise splitting using all possible predictor variables, seeking the variable values that minimize within-group sums of squares. Each group is repeatedly split until the proportional reduction in error (PRE) falls below a set percentage based on a least squares 
loss function. CART works best when there is a categorical response variable, so we changed the numeric overall scores to letter ranks, setting $A$ at 0.9 or above, $B$ at $0.75-0.89, \mathrm{C}$ at $0.50-0.74$, and D at 0.49 or below $^{3}$. CART represents interactions between predictor variables as branches from a split point, and continues to split data along each branch until a predefined goodness-of-fit criteria is not met, and the branch concludes in a terminal node. The process ends when all branches have terminal nodes, at which point users can "prune" the tree back to a specified number of terminal nodes. CART analyses were run on data at three different buffer distances: 200 meters, 500 meters, and 1,000 meters.

\section{Model Development}

Our intent was to use the results of the CART analysis to select metrics for a model that would capture condition classes across the state. However, the analysis did not yield enough metrics to do this. At this point, there were three major challenges:

1) The existing dataset did not completely capture the range of landscape-level stressors that exist across the state. For example, while there was a statistically significant relationship between both crop agriculture and urbanization and wetland condition, those relationships explained less than $1 \%$ of the variability in the data, simply because so few wetlands in the dataset were near urban or agricultural areas.

2) Similarly, the stressors affecting some of the low-scoring wetlands were not identifiable using the NLCD alone. This was in part due to the age of the imagery used in the NLCD: several areas that are classified as forested have been intensively logged in the past few years. When we included land ownership as a variable in our CART analysis, ownership by timber companies was a splitting factor.

3) In all analyses of our dataset at every buffer distance, the effect of environmental variables far outweighed the impacts of human disturbance. REAP appeared as the driving factor determining wetland condition.

One common goal of wetland assessment and monitoring programs is to evaluate the success of management efforts (Fennessy et al. 2004, Kentula 2007). By implication, wetland assessment tools should not incorporate both environmental variables such as precipitation and human disturbance variables like land use because doing so makes it difficult to determine what management actions could improve wetland condition.

However, several of our human disturbance metrics, though statistically significant, did not have strong enough relationships with wetland condition to support a model.

As noted earlier, most Level I assessment tools are expert systems developed by application of best professional judgment (Tiner 2005, Weller et al. 2007). Therefore, we decided to construct a landscape integrity model (LIM) incorporating both metrics derived from the analysis and our knowledge of landscape-level stressors. Landscape integrity models have been used as a stratification tool in development of fine-scale assessment methods in the Rocky Mountain West (Rocchio 2007). We thought that such a model, with scoring thresholds calibrated to existing assessment data, would meet our primary goals of identifying areas where high-quality wetlands were likely to be found and areas where wetlands might be most in need of management actions.

Our model used an inverse-weighted distance approach (Tuffly and Comer 2005) to create land cover and land use layers in a GIS. We used ANOVA and CART to evaluate each new layer against the assessment data. CART was also used to set weights and scoring thresholds. In doing so, we attempted to optimize use of layers derived from readily available datasets (e.g., land cover, roads, hydrology) while minimizing use of layers derived from datasets that might not be available in all Rocky Mountain states (e.g., cadastral, mines, energy, Clean Water Act Section 404 permits).

\footnotetext{
${ }^{3}$ The MTDEQ RAM form assigns categorical ranks at different cutoff points. We experimented with several thresholds in CART before concluding that these yielded the clearest results. These thresholds agree with those chosen by Faber-Langendoen et al. (2006) in their ecological integrity assessments.
} 
Table 3 shows the data layers included in model development. Appendix B contains a detailed description of how the model was developed and how individual data layers were weighted and scored.

Because REAP was seen as a major driver behind wetland condition, it cannot be ignored in Level I assessments. To separate environmental impacts from variables that are responsive to management action, we devised a scoring scheme that uses the final model in conjunction with REAP data.

\section{Model Calibration, Testing and Validation}

We calibrated the model to the MTDEQ-RAM scores in the initial 59l datapoints using raw numeric scores. The raster layer constituting the LIM assigns a score to each 30 -meter by 30 -meter pixel. To assign LIM scores to a wetland, we used Spatial Analyst's zonal statistics function to derive mean scores for buffered areas around each point $(100,300$ and 1,000 meters). We used the highest $\mathrm{R}$-squared value to identify the optimal buffer

Table 3. GIS data sources used in this report.

\begin{tabular}{|c|c|c|c|c|}
\hline TYPE & SOURCE & DATE & $\begin{array}{l}\text { CELL SIZE/ } \\
\text { RESOLUTION }\end{array}$ & SOURCE DATA \\
\hline Land Use & NLCD & 2001 & $30 \mathrm{~m}$ & $\begin{array}{l}\text { LandSAT TM (1993- } \\
2000)\end{array}$ \\
\hline $\begin{array}{l}\text { Hydrology } \\
\text { (Streams, rivers, } \\
\text { lakes, reservoirs, } \\
\text { hydrologic units) }\end{array}$ & NHD & 2007 & $1: 24,000$ & $\begin{array}{l}1: 24 \mathrm{k} \text { USGS } \\
\text { topographic maps }\end{array}$ \\
\hline Wetlands & USFWS & Varies & $1: 24,000$ & $\begin{array}{l}\text { National wetlands } \\
\text { inventory }\end{array}$ \\
\hline $\begin{array}{l}\text { Digital Elevation } \\
\text { Models }\end{array}$ & USGS & Varies & $30 \mathrm{~m}$ & $\begin{array}{l}1: 24 \mathrm{k} \text { USGS } \\
\text { topographic maps }\end{array}$ \\
\hline Roads & $\begin{array}{l}\text { TIGER/US } \\
\text { Census Bureau }\end{array}$ & 2001 & $1: 100,000$ & $\begin{array}{l}1: 100 \mathrm{k} \text { USGS } \\
\text { topographic maps }\end{array}$ \\
\hline $\begin{array}{l}\text { Relative } \\
\text { Effective Annual } \\
\text { Precipitation } \\
\text { (REAP) }\end{array}$ & NRCS & 2008 & $10 \mathrm{~m}$ & DEMs, DAYMET \\
\hline $\begin{array}{l}\text { Montana } \\
\text { cadastral data }\end{array}$ & $\begin{array}{l}\text { MT Base Map } \\
\text { Service Center }\end{array}$ & 2008 & N/A & $\begin{array}{l}\text { BLM GCDB } \\
\text { (boundaries) }\end{array}$ \\
\hline $\begin{array}{l}\text { Montana Public } \\
\text { Stewardship }\end{array}$ & MTNHP & 2008 & $1: 100,000$ & Varies \\
\hline $\begin{array}{l}\text { Water Rights } \\
\text { Points of Use }\end{array}$ & DNRC & Varies & $1: 100,000$ & $\begin{array}{l}\text { BLM GCDB } \\
\text { (boundaries) }\end{array}$ \\
\hline $\begin{array}{l}\text { Population } \\
\text { Density }\end{array}$ & $\begin{array}{l}\text { Montana State } \\
\text { Library }\end{array}$ & 2002 & $1 \mathrm{~km}$ & US Census Bureau \\
\hline Oil and gas wells & NRIS & Varies & Varies & $\begin{array}{l}\text { BLM, MBMG, } \\
\text { MDNRC }\end{array}$ \\
\hline Abandoned mines & MTDEQ & 2007 & 1/2 mile & MT DEQ \\
\hline CWA 404 permits & NRIS & 2003 & N/A & $\mathrm{ACOE}$ \\
\hline
\end{tabular}


area within which LIM scores should be averaged. We then used categorical MTDEQ-RAM ranks to define thresholds for each LIM rank, adjusting values until the highest accuracy ( $\%$ of modeled and measured ranks in agreement) was achieved. Next, we tested the calibrated model's agreement with ranks derived from the scores that had been assigned to the 100 test set data points in the field.

We validated the model on an independent set of wetlands $(n=180)$ assessed as part of this project during 2007 and 2008. These 180 wetlands consisted of 60 wetlands chosen from a spatiallydistributed, randomly selected set of 1,800 wetlands drawn from all mapped natural palustrine and lacustrine wetlands in the state. The remaining 120 wetlands were part of a targeted sample compiled to incorporate more environmental and disturbance gradients and to represent areas of the state that are not mapped. We also ran the model on the I,800 wetland dataset as a "dry run" of a Level I assessment procedure. To determine whether the model could predict wetland condition measured with other Level II assessment protocols, we compared it against a dataset of 108 Ecological Integrity Assessments (EIAs), a rapid field-based protocol we are currently testing in Montana (Appendix C).

Model accuracy was assessed by calculating the percentage of wetlands that were correctly classified into each rank category, using the LIM score as the predicted score and the MTDEQ-RAM score or EIA score as the measured score. Model acceptability was determined by calculating the percentage of wetlands that were either correctly classified or classified as being one rank higher than measured in the field with the MTDEQRAM or EIA. We reasoned that site-specific factors affecting the wetland could account for the difference if the measured condition was one rank lower than the predicted condition. However, if measured condition was one or more ranks higher or two ranks lower than predicted condition, this was considered to be unacceptable error. 


\section{Results}

\section{Initial Analysis: Step 1}

The 591 wetland data points used in the initial analysis were spread across five ecoregions (Omernik 1987): the Northwestern Great Plains $(n=207)$, the Northwestern Glaciated Plains $(n=122)$, the Northern Rockies $(n=125)$, the Middle Rockies $(\mathrm{n}=108)$, and the Canadian Rockies $(n=29)$. CART analysis showed a distinct ecoregional break in the data, with the three mountain ecoregions having significantly higher scores than the plains ecoregions. In the plains, the mean overall score on the MTDEQ-RAM was 0.75 (B) for the Northwestern Great Plains and 0.79 (B) for the Northwestern Glaciated Plains. In the mountains, the mean overall score was $0.92(\mathrm{~A})$ for wetlands in the Northern Rockies, 0.93 (A) for wetlands in the Middle Rockies, and 0.93 (A) for wetlands in the Canadian Rockies.

We evaluated land cover and land use metrics for the entire data set to identify metrics with a significant relationship to overall wetland condition score and an R-squared value of 0.20 or greater. Several metrics were significant at one or more scales, but no individual metric had an R-squared value at or above our target level. To determine whether we could find a combinations of metrics with some predictive value, we selected metrics that were significant across at least three of the four levels tested, and evaluated them using backward stepwise regression.

At the 6th code HUC, 1 kilometer, 500 meter, and 200 meter levels, the combined metrics of percent forest cover, road density, and number of stream road crossings had the strongest predictive value for overall score. However, the R-squared value for the three metrics combined was only 0.14 at the 6 th code HUC level. When measured at the buffer level, the combination of metrics had an even lower R-squared value. At 1,000 meters, the Rsquared value dropped to 0.13 , at 500 meters it was 0.11 , and at 200 meters, the $\mathrm{R}$-squared value was 0.09 , and road density was no longer significantly correlated with overall score.
The low and declining $\mathrm{R}$-squared values in the initial analysis, coupled with the ecorcgional skew in the dataset, suggested that the datasets might be better analyzed in two groups. From our field work, we knew that road density and road stream crossings are generally lower in the mountain ecoregions, while percent forest is generally higher. and so it appeared likely that the analysis was detecting ecoregional differences rather than the impact of land uses. Using ArcGIS, we divided the data into a plains set (Northwestern Great Plains and Northwestern Glaciated Plains) and a mountain set (Northern Rockies, Canadian Rockies, and Middle Rockies), and reran the analysis.

\section{Initial Analysis: Step 2}

With the data divided, percent forest was no longer significant at any scale. For wetlands in the mountain ecoregions ( $n=262$ ), road density was the only metric that was significant at all levels, although the R-squared value was never higher than 0.07 . At the 1,000 meter buffer, the percentage of crop agriculture was also significant ( $p<0.001$ R-squared $=0.08$ ), although it had no significance at other buffer distances. In the plains ecoregions, none of the metrics were significant at 200 meters. Percent natural grassland and road density within 500 meters were both significantly correlated with overall score but had very low $\mathrm{R}$ squared value ( 0.02 and 0.01 , respectively). At the 1,000 meter buffer scale, only the number of stream road crossings was significant. No metric was significantly correlated to overall wetland condition when measured at the 6th code HUC level in either the mountain dataset or the plains dataset.

Because no human disturbance factor appeared to explain the unbalanced distribution of scores among ecoregions, we turned to environmental factors. The pattern in the data suggested that some combination of precipitation and elevation was at play, so we reassessed the data using REAP as a variable. REAP was highly significant when evaluated against the entire dataset, (R-squared $=0.2 \mathrm{l}$ ). When we tested the predictive value 
of REAP within the two ecosystem groupings, it was only significant in the mountain regions ( $R$-squared $=0.13$ ). At the wetland sites in the mountain ecoregions, REAP ranged from 43 to 206 centimeters ( 17.2 to 82.4 inches), with a mean value of 104 centimeters (41.6 inches). By contrast, values at wetland sites in the plains ecoregions were much more tightly grouped, with a range from 27 to 62 centimeters ( 10.8 to 24.8 inches) and a mean of 35 centimeters ( 14 inches).

\section{CART Analysis}

The CART analysis was run with a proportional reduction in error (PRE) target set at 0.05 . We used all predictor variables, evaluating the data with metrics measured in the 1,000 meter buffer. However, for the dataset as a whole, no factor other than REAP reduced the PRE an additional 0.05 . The same was true when we set the PRE to 0.03. Dividing the data into mountain and plains groups failed to improve performance. At a PRE of 0.05 , REAP was the only splitting factor in mountain sites, while no splitting could be achieved in the plains sites. Because we were searching for predictor variables based on human disturbance, we then removed REAP as a predictor and ran the analysis again. In the mountains, road density equal to zero emerged as the first splitting factor, with percent natural grassland greater than $2.5 \%$ as the second. In the plains, no factor emerged until we set the PRE to 0.02 , where number of stream crossings produced a split.

We had similar results with all other buffer distances. In the mountains, the splitting factors remained the same. In the plains, stream road crossings dropped out entirely at 500 meter and 200 meter buffers. No factor split the data until road density emerged when we dropped the PRE to 0.01 .
In short, the CART merely reaffirmed the observations made with linear analysis. Most of the variation in our dataset was not explained by measured environmental factors or human-driven landscape factors, suggesting that site-specific factors may have the most pronounced impact on wetland condition ${ }^{4}$. However, we were also cognizant that the dataset itself was not ideal for building a data-driven model. Because of its design, many of the datapoints were concentrated in roadless areas with no measurable human impacts. Others were clustered in areas where road density was low but grazing pressures were high. Despite emerging as a significant predictor of wetland condition in the mountain ecoregions, crop agriculture occupied $10 \%$ or more of the 1,000 meter buffer at only four assessment sites.

\section{The Montana Landscape Integrity Model}

Our Montana Landscape Integrity Model (MTLIM) is an inverse weighted distance model premised on the idea that ecosystem processes and functions achieve their fullest expression in areas where human activities have the least impact. In the case of wetlands, it presumes that wetland condition will be poorest in close proximity to roads, commercial or industrial development, urban areas, resource extraction sites, or hydrologic modifications.

The model is built into a single raster layer covering the entire state. The raster pixel size is 30 meters by 30 meters, or 900 square meters. Pixel values range from 100 to 745 . Pixels with a value of 100 are beyond the furthest extent of any buffer distance for any impact (Figure 2). Conversely, pixels with high values $(>500)$ are typically in urban areas at the intersection of multiple stressors (Figure 3).

\footnotetext{
${ }^{4}$ We made several other attempts to extract patterns from the data using both CART and linear techniques. For example. because the scores from the randomly-drawn dataset were not evenly distributed -almost half the wetlands ivere ranked " $A$ " with a score of 0.9 or more - we drew a geographically stratified sample of 40 wetlands in each rank category from the overall dataset and repeated all the analyses described here. Again. only the factors that were seen as significant in the areas and at the scales described above stood out. and R-squared values were within the same ranges. We also added additional factors, evaluating land ownership, septic density. population density. management status, and water rights points of use. Although many factors were positively correlated to wetland condition, no factor, alone or in combination, had notable predictive value. Those having significance at several scales were incorporated into the expert model.
} 


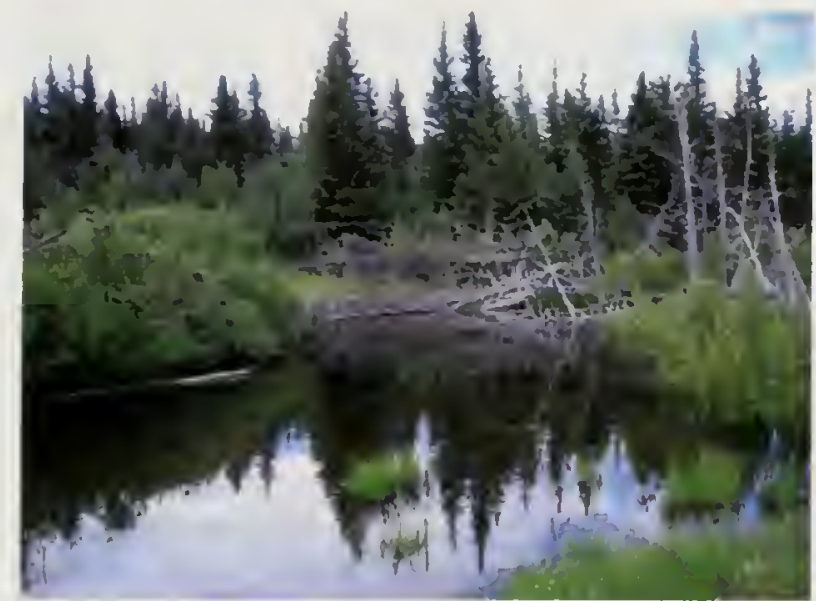

Figure 2. Wetland within high-integrity landscape.

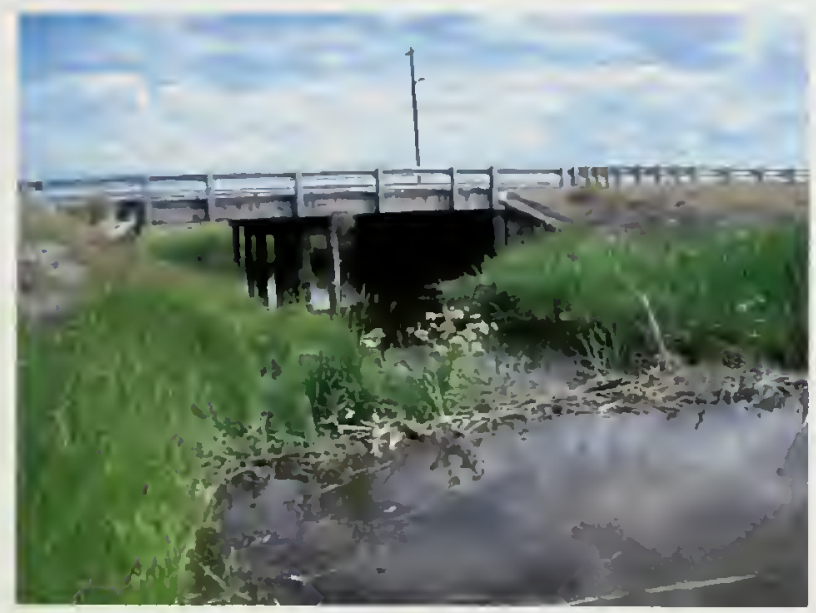

Figure 3. Hetland adjacent to multiple stressors.

We calculated Landscape Integrity Model (LIM) scores at three buffer distances, and regressed these scores against the raw MTDEQ-RAM overall scores. The mean LIM score calculated from pixels within 100 meters of the assessment point yielded the highest $\mathrm{R}$-squared value, 0.08 . The LIM did not account for significantly more variability than any of the individual metrics or combinations from the original analysis. Again, predictive value was very poor in the plains ecoregions ( $\mathrm{R}$-squared $=$ $<0.01$ ). In the mountain ecoregions, the predictive value of the LIM was stronger $(\mathrm{R}$-squared $=0.21)$.

Using CART analysis, we identified the combinations of REAP and LIM scores that best accounted for the variability in the data. After several iterations, we found that the formula yielding the best results was as follows (all REAP values are in centimeters):
$A=($ Mean $L I M \leq 120$ and REAP $\geq 30)$ OR (Mean LIM $\leq 180$ and REAP $\geq 50$ ) OR (Mean LIM $\leq 220$ and $R E A P \geq 60$ )

$B=($ Mean $\operatorname{LIM}<180$ and $>120$ and REAP $<50)$ OR (Mean LIM $\leq 120$ and REAP $<30$ ) OR (Mean LIM $<120$ and $>180$ and REAP $<60$ and $\geq 40$ ) OR (Mean LIM $\leq 400$ and $>220$ and REAP $\geq 30$ )

$\mathrm{C}=($ Mean $\mathrm{LIM}<220$ and $>180$ and REAP $<40)$ OR (Mean <350 and $>220$ and REAP <30) OR (Mean $\mathrm{LIM}>400$ and REAP $\geq 50$ )

$\mathrm{D}=$ Mean $\mathrm{LIM} \geq 400$ and $\mathrm{REAP}<50$

When we compared the rank assigned with these formulae to the rank assigned with the MTDEQ RAM on the original 591 data points and test datset of 100 points, $49.6 \%$ were classified accurately. Accuracy in the mountain ecoregions was higher $(74.8 \%)$. When applied to the 180 validation dataset points, $51 \%$ were classified correctly across all ecoregions, and $64.5 \%$ were classified accurately in the mountains. With both the calibration/test and validation datasets, accuracy was highest when predicting A-ranked wetlands in mountain areas ( $94 \%$ with the calibration/test data and $75 \%$ with the validation data). In the validation dataset, $65 \%$ of the plains wetlands and $83.5 \%$ of the mountain wetlands were classified acceptably, (i.e., the classifications were either accurate or no more than one rank higher than what was assigned in the field)

When compared to the Ecological Integrity Assessment scores, the classifications were accurate in 60 of 108 cases $(55.5 \%)$, even though) most of these assessments were conducted in the plains ecoregions. $74.07 \%$ of the assigned ranks were acceptable. The best performance was with B-ranked wetlands. where 45 of $70(64.2 \%)$ were correctly classified and $88.5 \%$ were classified acceptably.

In the dry-run Level 1 assessment of 1.800 wetlands that had been randomly selected for this project, $45 \%$ were ranked as $A, 44 \%$ were ranked as $B, 7 \%$ were ranked as $C$ and $4 \%$ were D. When only mountain ecoregions were 
considered $(n=1,187), 56 \%$ were ranked as $A, 35 \%$ were ranked as $\mathrm{B}, 3 \%$ were ranked as $\mathrm{C}$, and $6 \%$ were ranked as $\mathrm{D}$. This regional distribution of predicted ranks differs from the distribution of measured scores for the 591 points used in the analysis, mostly in the $B$ and $C$ ranks. Of the 591 datapoints assigned ranks based on MTDEQ-RAM scores, $48 \%$ were $\mathrm{A}, 25 \%$ were $\mathrm{B}, 21 \%$ were $\mathrm{C}$, and $6 \%$ were $\mathrm{D}$. In the mountain ecoregions, $75 \%$ were $\mathrm{A}, 16 \%$ were $\mathrm{B}, 8 \%$ were $\mathrm{C}$, and less than $1 \%$ were $D$. However, we note that the stratification schemes underlying the two datasets were very different. The amphibian survey dataset from which the 591 samples were drawn explicitly stratified along ownership gradients, and a high percentage of the datapoints in the mountains were drawn from managed public lands. By contrast, the sampling scheme for the 1,800 wetlands classified in this study did not use ownership as a strata. It may be that the higher percentage of A-ranked mountain wetlands in the MTDEQ-RAM dataset is explained by the fact that most occurred on public land, The wetlands selected for this project occurred across all ownership strata, and included many wetlands in proximity to developed mountain valleys in western Montana. 


\section{Discussion}

This study demonstrated the potential of landscapelevel metrics and models to predict wetland condition using remotely-sensed data in Montana. At the same time, it showed that environmental variables and site-specific activities may be far more important drivers of wetland condition than land uses occurring at a broader scale.

Further development of a landscape-level assessment tool will require a more robust set of field data. The MTDEQ-RAM, while useful for quick characterization of wetland impacts. is problematic insofar as it conflates stressors and condition. For example, across the entire state, proximity to roads and road density within buffers were the only landscape metrics that had a consistent negative correlation with overall wetland condition measured with the MTDEQRAM. However, proximity to roads is a metric in the MTDEQ-RAM buffer condition score, so the correlation may rest in large part on near-identical metrics rather than on any real causal relationship between road density and wetland condition. As we build new datasets using rapid and intensive Ecological Integrity Assessments, which separate condition metrics and human disturbance metrics, it will be useful to revisit this analysis. The fact that the Landscape Integrity Model and REAP data were better able to predict EIA scores in the plains ecoregions than MTDEQ-RAM scores is promising in this regard.

The results of this study also suggest that further model development should separate out the plains ecoregions and the mountain ecoregions. In the wide-open landscapes that characterize much of the plains, airborne weed seeds and dust can travel much further than in forested regions, so the distance at which individual landscape-level stressors operate may be greater. In our field studies, we have seen several cases where the presence of a thickly forested or shrubby buffer between a weed source and a wetland appears to protect the wetland from the spread of invasive plants. By contrast, in some areas of the plains, agricultural weeds or exotics are present in nearly all wetlands. This suggests that in the plains, metrics involving distance from crop agriculture or roads, the two land uses where soil disturbance is most common, could be rescaled. This would be most successful if it was based on additional field data that could support development of a clear relationship between buffer distance and presence of exotics and invasive plants in wetlands.

We did not do metric-by-metric correlations between landscape-level stressor variables and wetland condition variables. The MTDEQ-RAM metrics are semi-quantitative, but they rely heavily on subjective assessment by the user. For example, question 3.2, under "Hydrogeomorphology Condition" asks the user to assess "[d]egree of wetland habitat negatively altered by addition or withdrawal for irrigation, livestock watering, drainage, etc." with the possibilities being "Nonoccuring/slight (10 points)," "Moderate (4 points)" or "Severe (0)." Similarly, the "Vegetation Condition" metric 4.1 asks the user to evaluate "How much emergent vegetation is impacted by trampling or other human-caused disturbance?" with the choices being "None present/minimal (10 points)," "Some present 6-15\% (8 points)," "Common occurrence I6-25\% (4 points)" or "Very apparent $>25 \%$ ( 0 points)." If the assessment data were fully quantified, we think that metric-tometric comparisons would help to sharpen the data and to tease out differences between ecoregions (Hychka et al. 2007).

Of course. the best results will be obtained when Level I assessment metrics are calibrated against Level III data collected by expert users. The MTDEQ-RAM was designed for use by field crews with only enough botanical knowledge to identify a small suite of exotic plant species (reed canarygrass, smooth brome, quack grass, Kentucky bluegrass, creeping bent grass, meadow foxtail, tall fescue, timothy, sweet clover, and Russian olive) and noxious weeds (tamarisk. Canada thistle, whitetop cress, spotted knapweed, leafy spurge, purple loosestrife, yellowflag iris, and Eurasian milfoil). We think that one of the reasons the Landscape Integrity Model and REAP data were more accurate when predicting ranks obtained with 
EIAs is that the EIAs require users to be able to evaluate the degree to which the vegetation departs from reference standard communities expected in a given ecological system, and to be able to quantify the percent of all exotics and invasive plant species present. Although EIAs are also only semiquantitative, this improvement in performance suggested that better field data will yield better Level I assessment metrics.

We should note, too, that we calibrated Landscape Integrity Model scores to yield the highest overall accuracy, but that our results may favor wetlands in mountain ecoregions simply because that is where most of the A-ranked wetlands in the dataset occur. Again, had we been working with more precise data, it would have been worthwhile to attempt separate calibrations. However, without statistically significant relationships between wetland condition in the plains and most of the individual landscape metrics that went into the LIM, this seemed premature.

We also have not found a way to capture the effects of grazing, which can be both a site-specific stressor, as when livestock enter the wetland, or a landscape-level stressor, when they remove vegetation from the buffer area. Currently, no large-scale GIS grazing layer exists. On a local scale, it might be possible to characterize grazing intensity using animal unit months (AUMs) obtained from land management agencies if the area in question is under their jurisdiction. Similarly, it may be possible to use image classification to parse out rangelands into condition classes based on spectral signatures, but this has not been done for the state as a whole, and is a time-consuming and expensive effort that itself requires substantial ground truth data.

One of the questions raised by this study is whether plains wetlands, in general, are in poorer condition than mountain wetlands. This was suggested both by the MTDEQ data and by running the model on a randomly selected, spatially distributed set of wetlands across the state. We note several reasons that this may be so. First, in a period of protracted drought, wetlands in more arid regions would be more severely impacted. Wetland obligate plants will be more stressed, and competition with both facultative wetland and facultative upland species will increase. In cases where wetland obligate species have low palatability to livestock and wildlife and facultative upland plant palatability is high, drought-induced shifts in plant communities (e.g., a shift from an Eleocharis palustris association to a Pascopyrum smithii-Eleocharis spp. association) may increase grazing pressure. A second explanation lies in the simple fact that wet places in dry areas attract more human disturbance in the form of water impoundments, diversions and stock water development. Although we selected only wetlands that field crews had labeled "natural" for our analysis, examination of aerial photography and NWI maps indicated that many of these "natural" wetlands were dammed, diked, or receiving water flow from upstream reservoirs. A third factor, related to the first two, is resilience. Drought-stressed wetlands, or seasonally flooded wetlands undergoing earlier drawdown will have more bare ground for longer periods, facilitating establishment of exotics and invasive plant species. The same is true of wetlands disturbed by direct human influences. Even if livestock is removed or hydrological modifications are abandoned, it may be some time before soil and moisture conditions allow for a return of native wetland plant communities. Therefore, we think it is likely that plains wetlands are, overall, more likely to be in good-to-fair condition rather than the excellent-to-good condition found in the mountains. However, we also note that most of the intensive human developments (cities, recreation areas) found in Montana occur in the mountains, and that a different sampling scheme, geared to characterizing wetland condition across a basin or ecoregion rather than to surveying amphibians, would be necessary to generate a dataset that could answer this question conclusively. 


\section{How to Use the Landscape Integrity Model}

Landscape-level assessments are a rough surrogate for site-specific measurements of human-induced disturbances that may affect wetland condition (Hychka et al. 2007. Wardrop et al. 2007). They are not themselves assessments of condition and cannot substitute for site-specific evaluations. However, there are several cases where use of the Landscape Integrity Model and REAP data would be appropriate:

\section{Characterize and compare wetland disturbance} or likely wetland condition across a geographic area. Ranks derived from the LIM and REAP data can be displayed at multiple scales. At the full state level, such displays can illustrate the distribution of stressors across regions of the state. Figure 4 , for example, shows the 1,800 randomly selected points scored for this study. A-ranked wetlands are clustered in the mountain regions, while B- and $\mathrm{C}$-ranked wetlands are more concentrated in the plains. Similar characterizations could also be made at smaller scales if digital wetland maps are availables.

2. Characterize watersheds or other geographic units. If wetland maps are not available, or if users simply want to characterize a landscape rather than individual wetlands, then the LIM can be used as a general landscape assessment tool. For example, watershed assessments typically include some sort

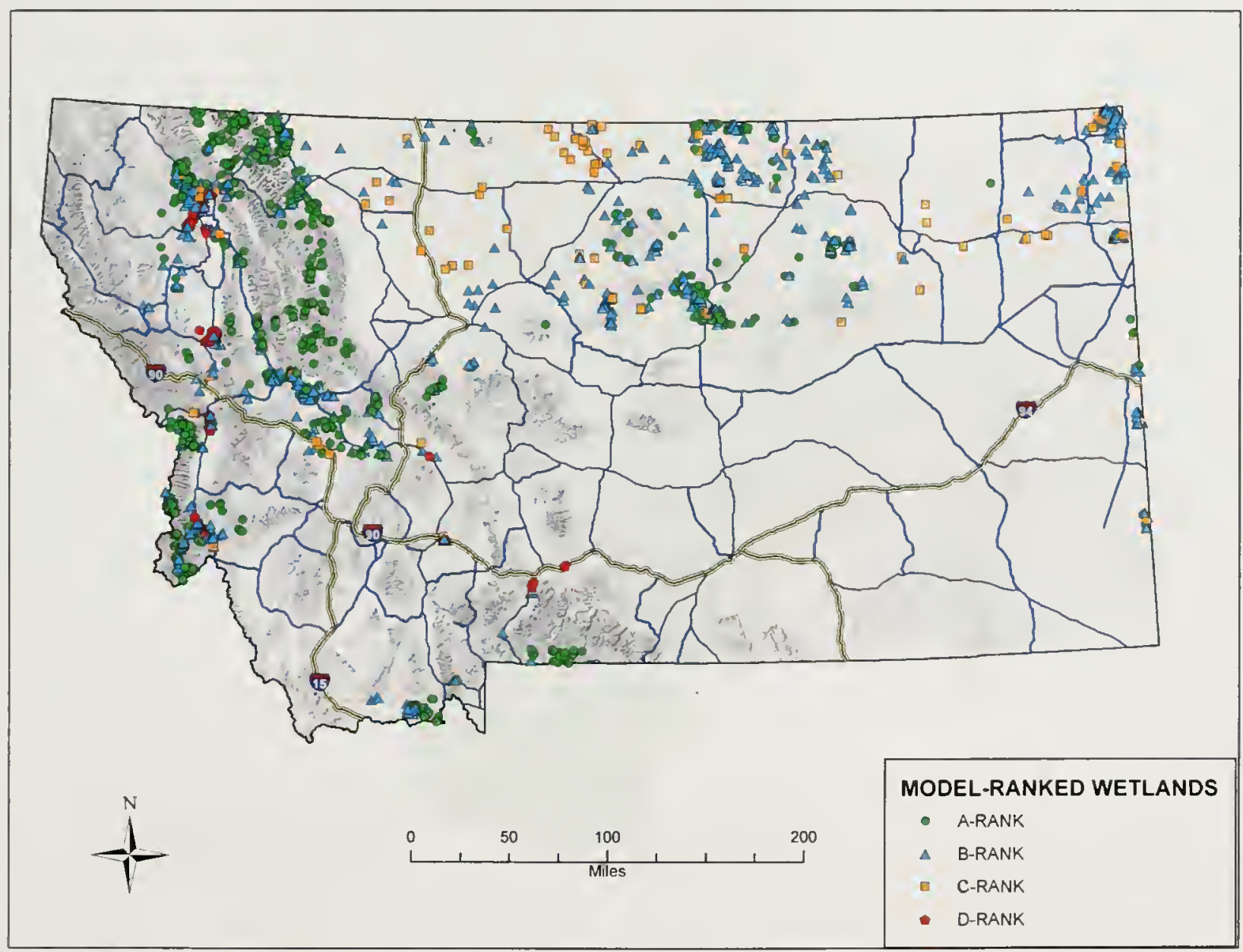

Figure t. Model-ranked wetlands.

\footnotetext{
5 If digital wetland maps are available. we would recommend using a revised LIM incorporating an "altered wetland" raster. We did not do this because the goal was a model that would be usable statewide: if we had been making a model for a specific subbasin. with wetland mapping. we would have substituted altered wetlands for other hydrologic alterations.
} 
of synthesis of stressors, threats, or disturbances (e.g., Vance and Stagliano 2007, 2008). When these are carried out at the basin, subbasin, or watershed level, nested hydrologic units can be compared and contrasted. Figure 5, which shows the Ruby Valley subbasin in Southwest Montana, displays average LIM scores calculated for each subwatershed, and provides a quick snapshot of the distribution of stressors across the subbasin. More precise versions of the display can show LIM scores for each pixel, allowing users to focus on more specific areas. Figure 6 depicts the same subbasins with non-aggregated LIM scores, allowing users to visualize areas of highest and lowest integrity.

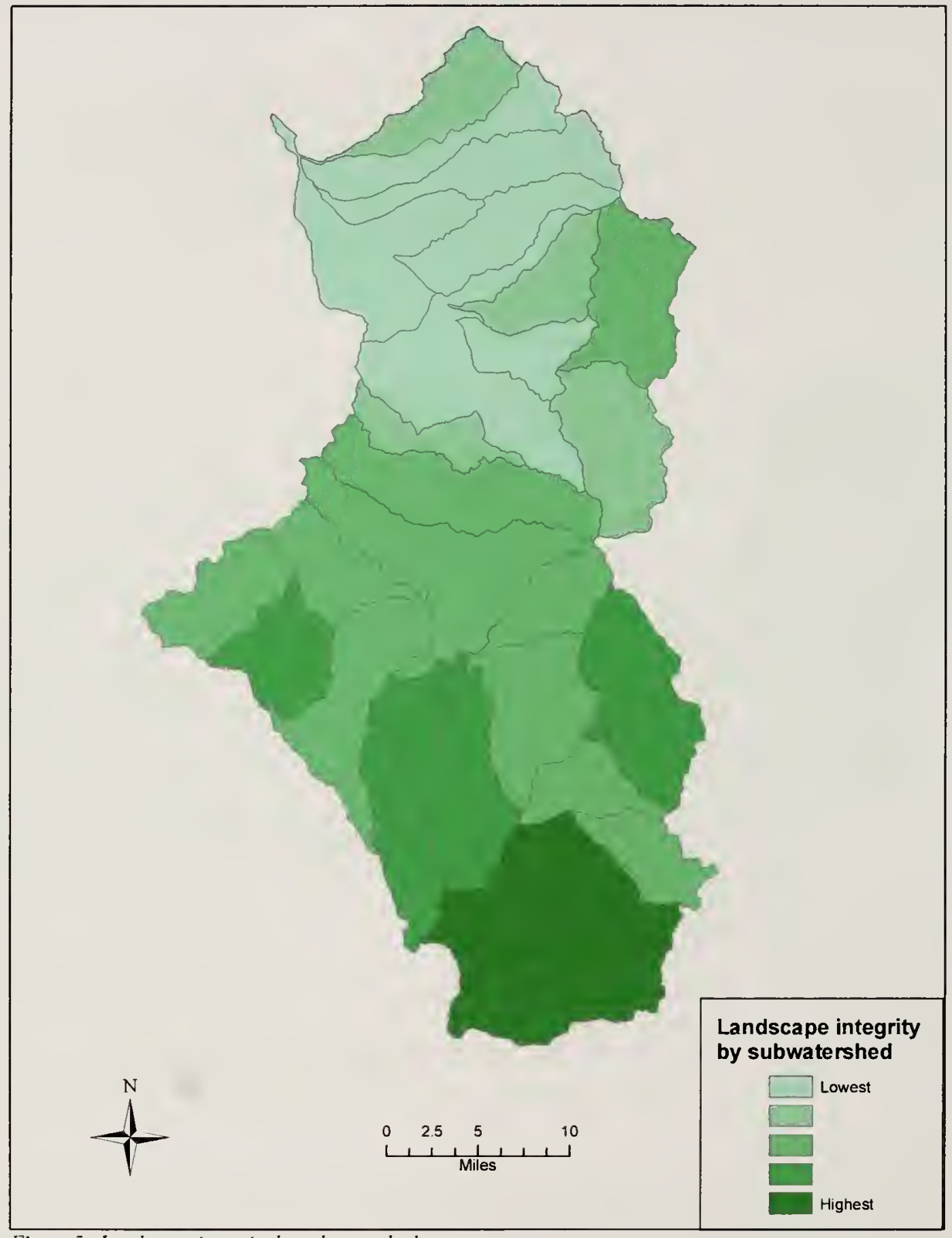

Figure 5. Landscape integrity by subwatershed. 


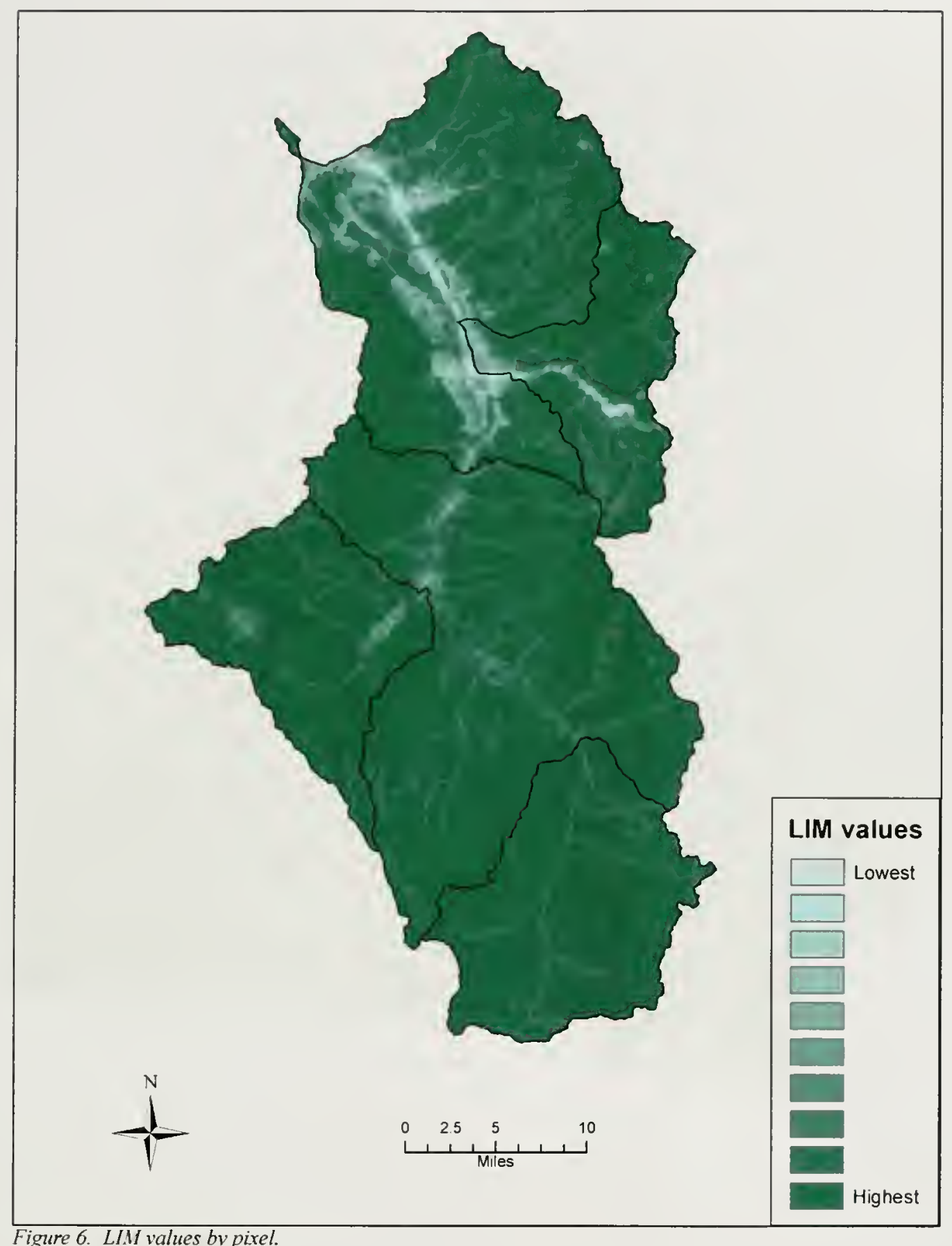

3. Identify high-integrity hot spots where high quality wetlands are likely to be found. Although site-specific disturbances will always be a possibility, the LIM can be used to locate areas where large-scale, negative human influences are minimal. To create Figure 7, we used a conditional statement in Spatial Analyst to identify pixels with a LIM value of I00 (no human impacts). Then we used block statistics in Spatial Analyst to calculate average scores over 3 kilometer by 3 kilometer blocks. Block statistics could be calculated for larger or smaller areas, but this area allows a user to pick out contiguous areas of high integrity. Figure 8 is zoomed into northwestern Montana, where the populated Flathead Valley and surrounded timberlands contrast sharply with the pristine sections of Glacier National Park and the Middle Fork Flathead watershed. In this case, 
the map would direct searches for high-quality wetlands (or other natural features) towards the blocks defined as highest integrity.

4. Combine with other tools to conduct desk-based assessments of individual wetlands. The wetland in Figure 9 was classified to an A-rank with the LIM score and REAP data. In the field, it was ranked as a C. Examination of the high-resolution imagery taken in 2005 explains why. First, the wetland itself has been excavated, as have several in the area. Cattle paths are visible to the west of the wetland, and a road (not depicted on any GIS layer) is evident to the north. If LIM and REAP scores are used as individual metrics and additional metrics are developed (e.g., evidence of grazing within a I-km buffer, percent altered wetlands within a $1-\mathrm{km}$ buffer, length undigitized roads or two-tracks, etc), then accuracy would be greatly improved in many cases. The same would be true in forested areas, where clearcuts and fires may have occurred after the GIS datasets were created, but prior to acquisition of the high-resolution imagery in 2005.

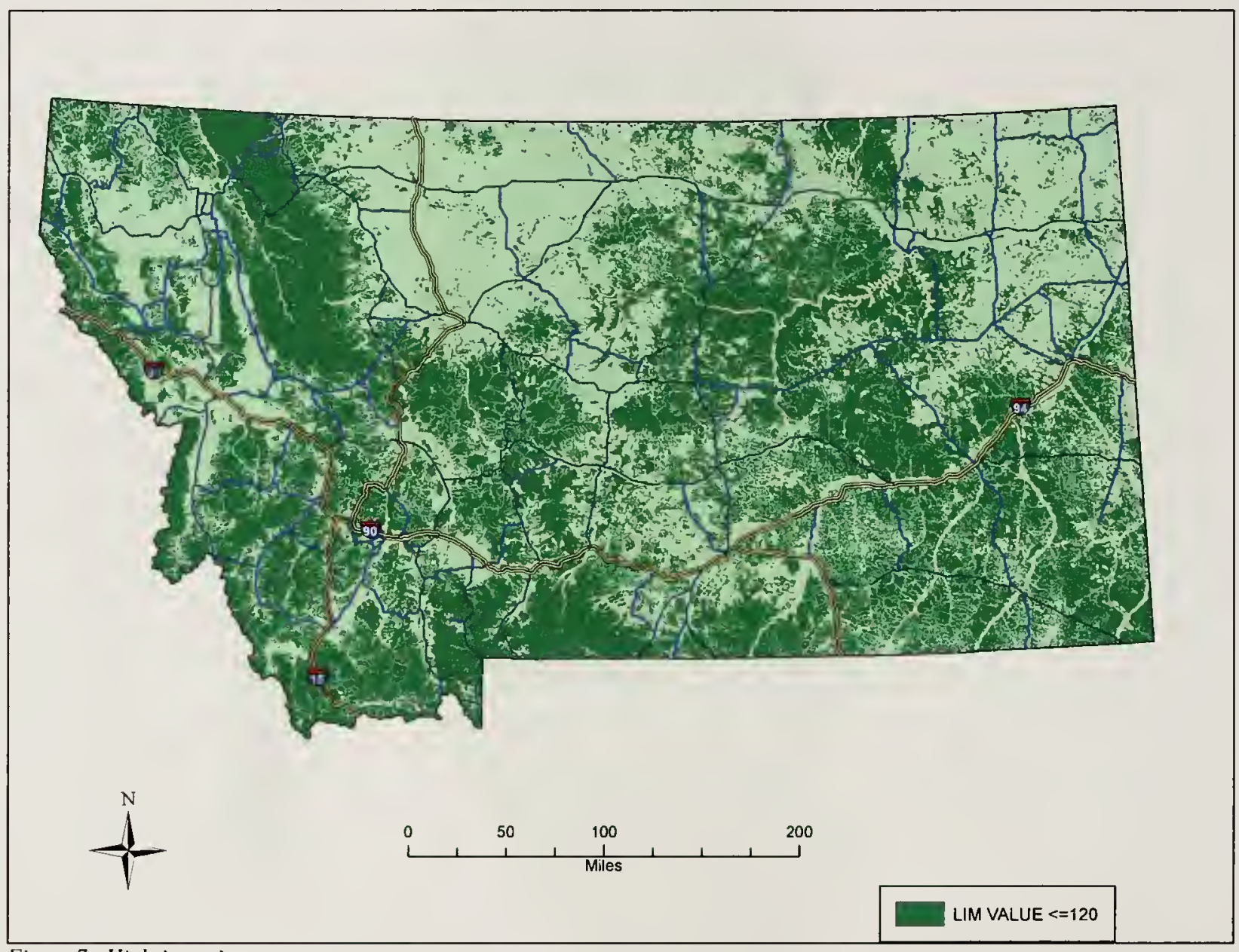

Figure 7. High-integrity areas. 


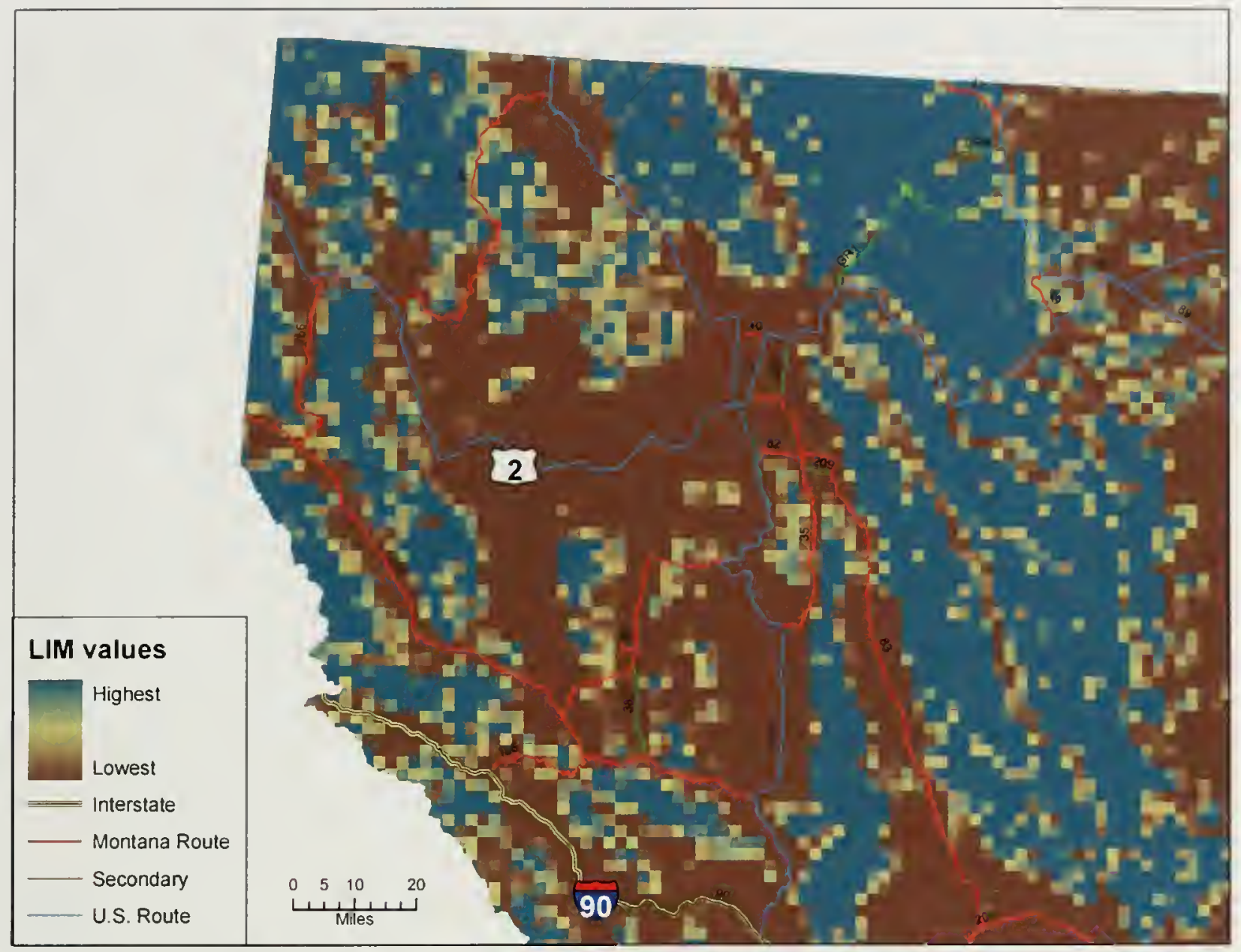

Figure 8. Northwestern. Montana LIM blocks. 


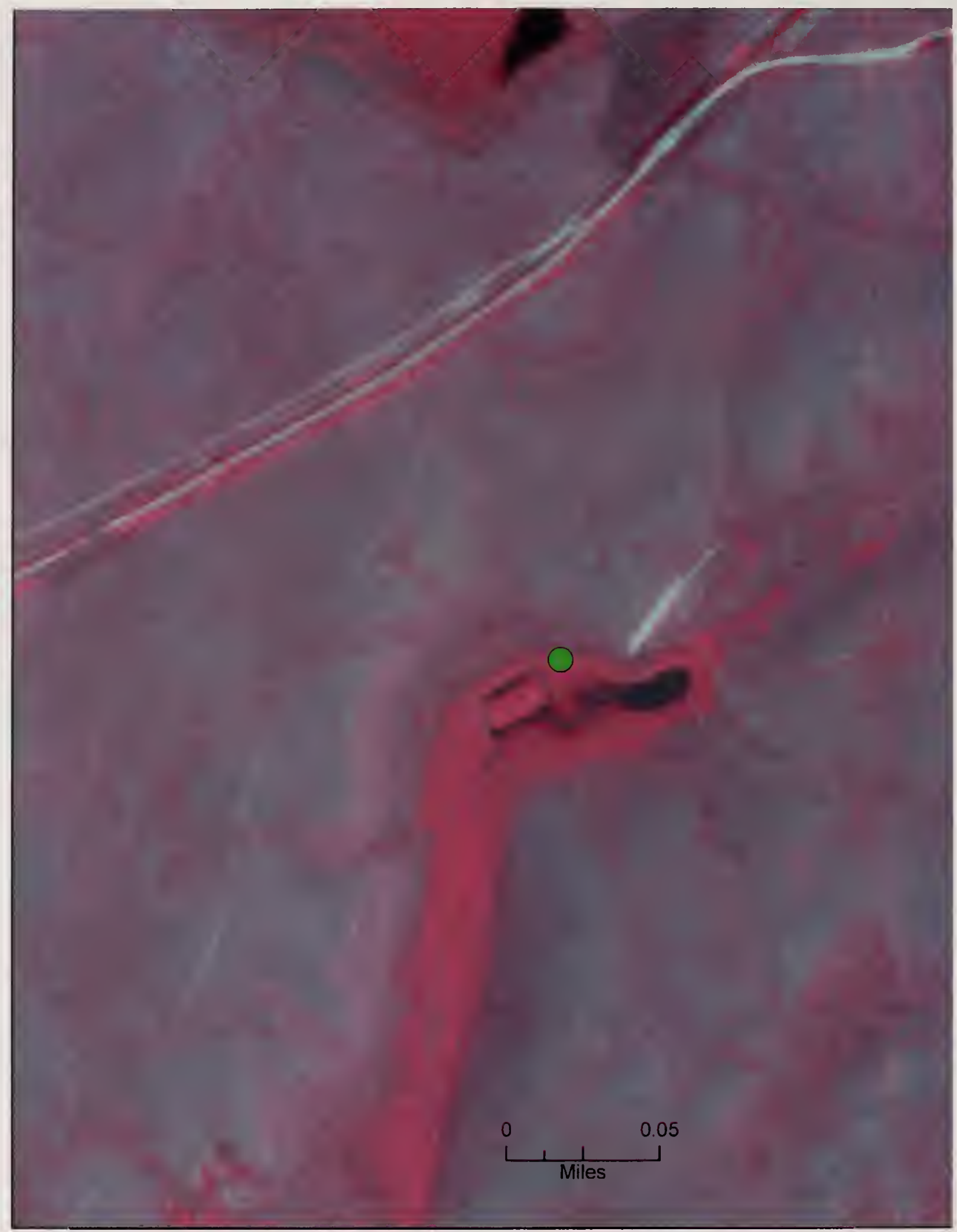

Figure 9. Misclassified wetland. 


\section{Conclusions}

Human disturbances can affect wetlands at multiple scales, and because they tend to interact both with each other and with environmental variables, it is exceedingly difficult to quantify or predict their effects. In many parts of Montana, environmental variables, particularly precipitation, may be the most influential drivers of wetland condition. Nevertheless, by integrating human disturbances through a GIS, we were able to build a model of landscape integrity that can be combined with precipitation data to generally categorize wetlands into condition ranks. While we would caution against using this approach to rank any one wetland, we think that it offers a way to quickly characterize the condition of wetlands across an entire subwatershed or watershed and to compare wetland condition in different geographic areas.
Ultimately, landscape-level wetland assessment may never be a satisfactory substitute for field assessments. Even in rural states like Montana, pockets of rapid development soon make derived image classification products like the NLCD obsolete. Similarly, natural stressors like insect outbreaks and disease are having widespread impacts on our forests, and salvage logging operations are likely to increase in coming years. Nonetheless, when field assessments are not practical, landscape-level assessment is the only alternative. With completion of the Landscape Integrity Model and an approach for integrating it with precipitation data, we now have a tool offering a quick and efficient way to begin that task. 


\section{Literature Cited}

Allan, D. 2004. Landscapes and riverscapes: the influence of land use on stream ecosystems. Annual Review of Ecology, Evolution and Systematics 35:257-265.

Brazner, J.C., N.P. Danz, A.S. Trebitz, G.J. Niemi, R.R. Regal, T. Hollenhorst, G. E. Host, E.D. Reavie, T.N. Brown, J. M. Hanowski, C.A. Johnston, L.B. Johnson, R.W. Howe, and J.H. Ciborowski. 2007. Responsiveness of Great Lakes Wetland Indicators to Human Disturbances at Multiple Spatial Scales: A Multi-Assemblage Assessment. Journal of Great Lakes Research 33:42-66.

Brooks, R.P., D.H. Wardrop and J.A. Bishop. 2004. Assessing wetland condition on a watershed basis in the Mid-Atlantic Region using Synoptic Land-Cover Maps. Environmental Monitoring and Assessment 94:9-22.

Brown, M.T. and B. Vivas. 2005. Landscape development intensity index. Environmental Monitoring and Assessment 101:289-309.

De'Ath, G. and K.E. Fabricus. 2000.

Classification and regression trees: a powerful yet simple technique for ecological data analysis. Ecology 81(11): 3178-3192.

Ebert, D.W., and T.G. Wade. 2000. Analytical Tools Interface for Landscape Assessments (ATILA) User Guide: Version 2.0. Office of Research and Development. U.S. Environmental Protection Agency. Las Vegas, NV. 23pp.

ESR1. 2000. ArcG1S 3.3. Environmental Systems Research Institute. Redlands, CA.

ESRI. 2006. ArcG1S 9.3. Environmental Systems Research Institute. Redlands, CA.
Faber-Langendoen, D., J. Rocchio, M. Schafale, C. Nordman, M. Pyne, J. Teague, T. Foti, and P. Comer. 2006. Ecological Integrity Assessment and Performance Measures for Wetland Mitigation. Final Report, March 15, 2006. NatureServe, Arlington, VA.

Faber-Langendoen, D., G. Kudray, C. Nordman, L. Sneddon, L. Vance, E. Byers, J. Rocchio, S. Gawler, G. Kittel, S. Menard, P. Comer, E. Muldavin, M. Schafale, T. Foti, C. Josse, J. Christy. 2008. Ecological Performance Standards for Wetland Mitigation: An Approach Based on Ecological Integrity Assessments. NatureServe, Arlington, VA.

Fennessy, M.S., A.D. Jacobs, and M.E. Kentula. 2004. Review of Rapid Methods for Assessing Wetland Condition. U.S. Environmental Protection Agency. Washington, DC, USA. EPA/620/R-04/009.

Gregory, S.V., F.J. Swanson, W.A. McKee, and K.W. Cummins. 1991. An Ecosystem Perspective of Riparian Zones. BioScience 41(8): 540-551.

Hychka, K.C., D.H. Wardrop and R.P. Brooks. 2007. Enhancing a landscape assessment with intensive data: a case study in the Upper Juniata watershed. Wetlands 27: 446-461.

Kentula, M.E. 2007. Foreword: Monitoring wetlands at the watershed scale. Wetlands 7:412-415.

LaGory, K.E. and J.A. Kuiper. 2004. Modelling the suitability of potential wetland mitigation sites with a geographic information system. Environmental Management 33:368-375.

Mack, J.J. 2007. Developing a wetland IBI with statewide application after multiple testing iterations. Ecological Indicators 7: 864-881. 
Magee, T.K., and M.E. Kentula. 2005. Response of wetland plant species to hydrologic conditions. Wetlands Ecol. Mgt. 13:163-181.

Mita, D., E. DeKeyser, D. Kirby and G. Easson. 2007. Developing a wetland condition prediction model using landscape structure variability. Wetlands 27: 1124-1133.

Montana Department of Environmental Quality. 2005. Montana Wetland Rapid Assessment Method. Available at: http:// www.deq.state.mt.us/wqinfo/wetlands/ FnlDrftGdebkRAMDEC05.pdf. Last accessed January 20, 2009.

NRCS. 2008. Montana REAP data. Available at: http://nris.mt.gov/nres/reap/. Last accessed January 19, 2009.

Omernik, J.M. 1987. Ecoregions of the conterminous United States. Map (scale 1:7,500,0000). Annals of the Association of American Geographers 77:118-125.

Phillips, R.L., O. Beeri, and E.S. DeKeyser. 2005. Remote wetland assessment for Missouri Coteau prairie glacial basins. Wetlands 25:335349.

Rocchio, J. 2007. Assessing ecological condition of headwater wetlands in the southern Rocky Mountain Ecoregion using a vegetation index of biotic integrity. Unpublished report prepared for Colorado Department of Natural Resources, and U.S. Environmental Protection Agency, Region VIII. Colorado Natural Heritage Program, Colorado State University, Fort Collins, CO. Available at: http://www.cnhp. colostate.edu/reports.html.

Skagen, S.K., C.P. Melcher and D.A. Haukos. 2008. Reducing sedimentation of depressional wetlands in agricultural landscapes. Wetleands 28: 594-604.
Tiner, R.W. 2005. Assessing cumulative loss of wetland functions in the nanticoke river watershed using enhanced national wetlands inventory data. Wetlands 25:405-419.

Tuffly, M. and P. Comer. 2005. Calculating Landscape Integrity: A Working Model. DRAFT. 4/19/2005. Available at: https:// conserveonlinc.org/workspaces/human.activity. index/li data 4 19_2005.doc. Last accessed February 2, 2009.

Vance, Linda K. and David M. Stagliano. 2007. Watershed Assessment of Portions of the Lower Musselshell and Fork Peck Reservoir Subbasins. Report to the Bureau of Land Management, Lewistown Field Office. Montana Natural Heritage Program, Helena, Montana 41 pp. plus appendices.

Vance, Linda K. and David M. Stagliano. 2008. Watershed Assessment of Portions of the Clark's Fork Yellowstone, Bighhorn Lake, and Shoshone Subbasins, Montana and Wyoming. Report to the Bureau of Land Management, Montana / Dakotas State Offices. Montana Natural Heritage Program, Helena, Montana 45 pp. plus appendices.

Wardrop, D.H. , M.E. Kentula, D.L. Stevens Jr., S.F. Jensen, and R.P. Brooks. 2007. Assessment of wetland condition: an example from the Upper Juniata Watershed in Pennsylvania, USA. Wetlands 27:416-31.

Weller, D.E., M.N. Snydar, D.F. Whigham, A.D. Jacobs and T.E. Jordan. 2007. Landscape indicators of wetland condition in the Nanticoke River Watershed, Maryland and Delaware, USA. Wetlands 27:498-514. 
ApPendix A. MTDEQ Rapid Assessment Form 



\section{Montana DEQ - Wetland Rapid Assessment Form (version 2.0)}

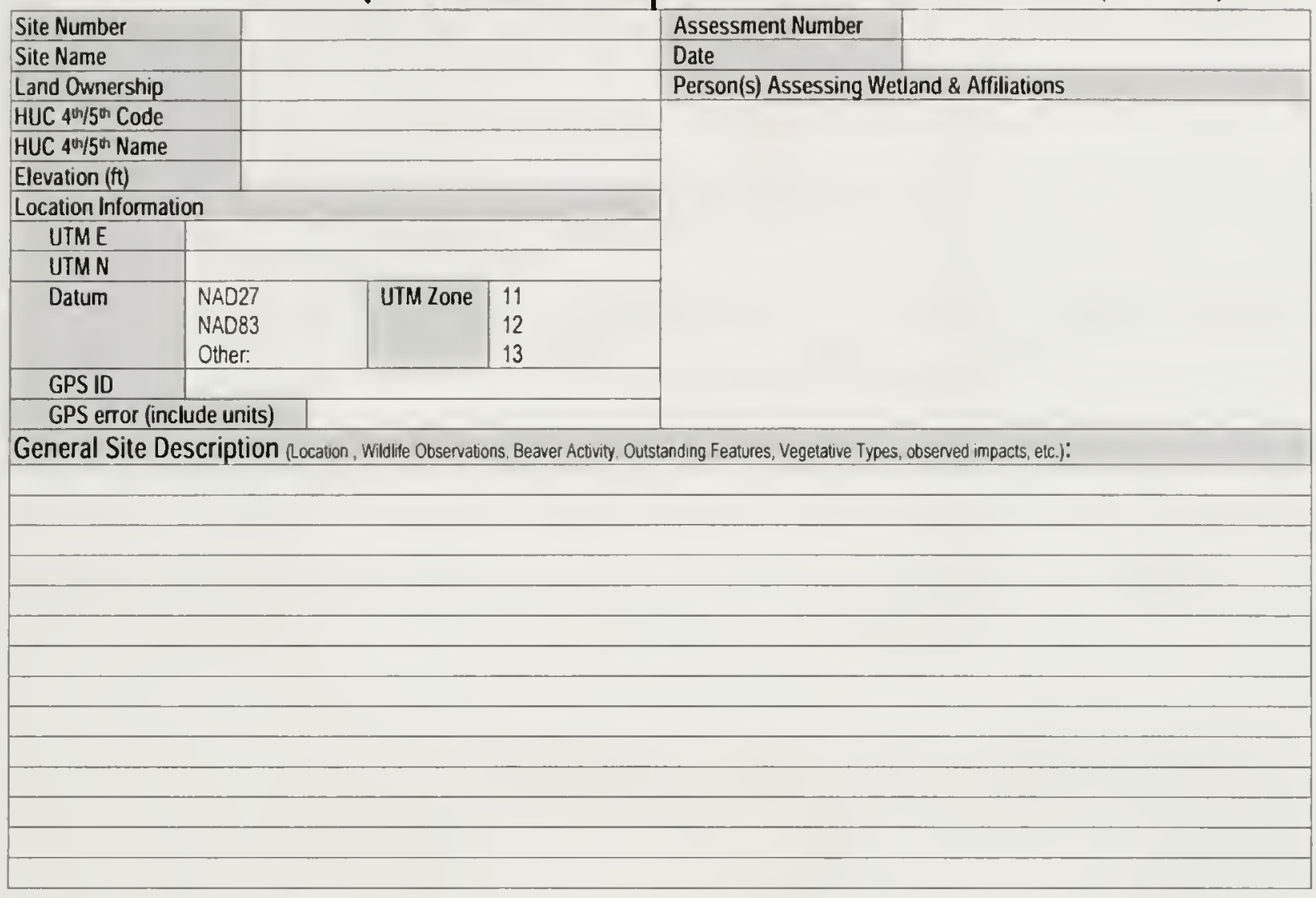

Photos:

\begin{tabular}{|l|l|l|}
\hline Photo \# & Direction Facing & Description of what is in the photo \\
\hline & & \\
\hline & & \\
\hline & & \\
\hline & & \\
\hline & & \\
\hline & & \\
\hline & & \\
\hline & & \\
\hline
\end{tabular}

\subsection{Wetland Classification}

\begin{tabular}{|l|l|l|l|}
\hline 1.1 Wetland is being assessed to reflect (Circle) & $1.2 \mathrm{HGM}$ Classification (Circle one Class or Subclass) \\
\hline Natural Wetland Type (assess potential) & Riverine & Depressional & Lacustrine Fringe \\
\hline Altered Wetland Type (assess capability) & Upper Perennial & Closed & Open Spring \\
Completely Altered (no longer functioning as a wetland, & Lower Perennial & Open groundwater & Playa Lakes \\
and it is not feasible lo survey wetland condition) & Non-Perennial, & Open surface water & Rivenne Spring \\
'What alterations have been made? & Intermittent or & & Fen \\
\hline
\end{tabular}




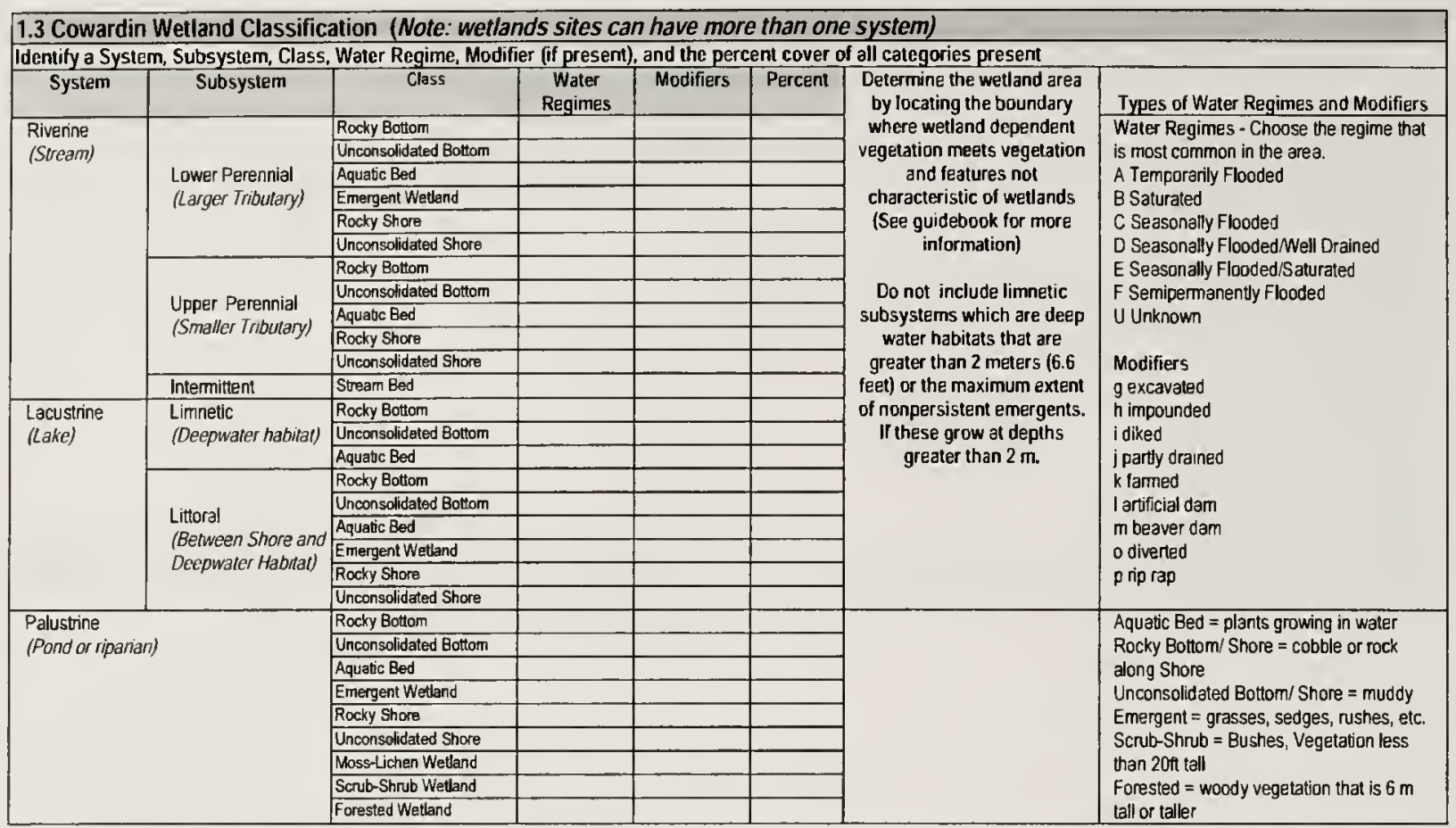

\subsection{Site Characterization \\ \begin{tabular}{|l|l|l|l|l|l|}
\hline 2.1 Are Fish Present? & Yes & No & N._. Not Sure & Species (if known)?] \\
\hline
\end{tabular}}

2.2 Amphibian and Aquatic Reptile Species Observed - check and describe life stage below: Eggs, tadpole, adult

\begin{tabular}{|l|l|l|l|}
\hline Common Name & Life Stage & Common Name & Life Stage \\
\hline Boreal Chorus Frog & & Snapping Turtle & \\
\hline Bullfrog & & Spiny Softshell & \\
\hline Coeur D'Alene Salamander & & Tiger Salamander & \\
\hline Columbia Spotted Frog & & Western Hognose Snake & \\
\hline Common Gartersnake & & Terrestrial Gartersnake & \\
\hline Great Plains Toad & Westem Toad & & \\
\hline Westem Skink & & Woodhouse's Toad & \\
\hline Smooth Greensnake & & Other (describe if unknown): & \\
\hline
\end{tabular}

\begin{tabular}{|l|l|}
\hline Common Name & Life Stage \\
\hline Long-toed Salamander & \\
\hline Northem Leopard Frog & \\
\hline Pacific Treefrog & \\
\hline Painted Turtle & \\
\hline Plains Garter Snake & \\
\hline Plains Spadefoot & \\
\hline Rocky Min Tailed Frag & \\
\hline
\end{tabular}

2.3 Estimate the Percent of Standing Water

\begin{tabular}{|l|l|l|l|l|l|l|}
\hline Percentage of standing water body $<50 \mathrm{~cm}$ depth & 0 & $1-25$ & $26-50$ & $51-75$ & $76-100$
\end{tabular}

\begin{tabular}{|l|l|l|l|l|}
\hline Percentage of standing water body $50-200 \mathrm{~cm}$ depth & 0 & $1-25$ & $26-50$ & $51-75$ \\
\hline
\end{tabular}

Percentage of standing water body $>200 \mathrm{~cm}$ depth

\begin{tabular}{|c|c|c|c|}
\hline Check & Species & Region Found & Status \\
\hline & Least Tem & Near Fort Peck Dam \& Miles City & Endangered \\
\hline & Whooping Crane & Northeastem Montana & Endangered \\
\hline & Bald Eagle & Entire region & Threatened \\
\hline & Piping Plover & North-central and Eastern portions of the state & Threatened \\
\hline & Black-Footed Ferret & Northeastem Montana & Endangered \\
\hline & Canada Lynx & Entire region & Threatened \\
\hline & Gray Wolf & Entire region & Threatened/Endangered \\
\hline & Grizzly Bear & Greater Yellowstone, Northem Continental Divide, Cabinet-Yaak, Bitterroot Selway Ecosystems & Threatened \\
\hline & Bull Trout & Entire Region & Threatened \\
\hline & Pallid Sturgeon & For Peck \& Yellowstone River below Powder River mouth & Endangered \\
\hline & White Sturgeon & Kootenai River & Endangered \\
\hline & Water Howellia & Northwestem Montana & Threatened \\
\hline & Ute Ladiest ${ }^{*}$ Tresses & Southwest and Southcentral Montana & THreatened \\
\hline leas & comment on what & was observed (scat, tracks, etc.): & \\
\hline
\end{tabular}




\begin{tabular}{|c|c|c|c|c|c|c|c|c|c|}
\hline \multicolumn{5}{|c|}{2.5 Check amt of surface area of any emergent vegetation } & \multirow{9}{*}{ 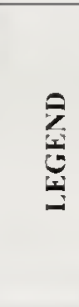 } & & & & \multirow[b]{2}{*}{ Trees } \\
\hline Type & $1-25 \%$ & $25-50 \%$ & $50-75 \%$ & $76-100 \%$ & & 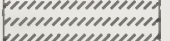 & Grasses & & \\
\hline \multicolumn{5}{|l|}{ Sedges } & & & \multirow{3}{*}{ Sedges } & & \multirow{2}{*}{ Photo } \\
\hline \multicolumn{5}{|l|}{ Cattails } & & & & & \\
\hline \multicolumn{5}{|l|}{ Grasses } & & & & & \multirow[b]{2}{*}{ Shruhs } \\
\hline \multicolumn{5}{|l|}{ Rushes } & & & \multirow{2}{*}{ Rushes } & & \\
\hline \multicolumn{5}{|l|}{ Waterlilies } & & \multirow{3}{*}{ } & & & \multirow{3}{*}{$\begin{array}{l}\text { Assessment } \\
\text { Bourdary }\end{array}$} \\
\hline \multicolumn{5}{|l|}{ Shrubs } & & & \multirow[t]{2}{*}{ Fence } & $-\cdots+\cdots$ & \\
\hline \multicolumn{5}{|l|}{ Trees } & & & & & \\
\hline Other & & & & & \multicolumn{2}{|c|}{ Please describe: } & & & \\
\hline
\end{tabular}

\subsection{Site Map for Wetland Assessment Area}

(site map can be substituted with a high-resolution aerial photo)

For Riverine sites: include length $=100 \mathrm{~m}$, width=as wide as outermost meander. For all other sites: $100 \mathrm{~m} \times 100 \mathrm{~m}$ or the entire wetland, if smaller. Buffer occupies $100 \mathrm{~m}$ on either side of the wetland. Specifics for determining assessment area are available in the handbook.

Grid Scale: 1 square $=$ $\mathrm{m}$

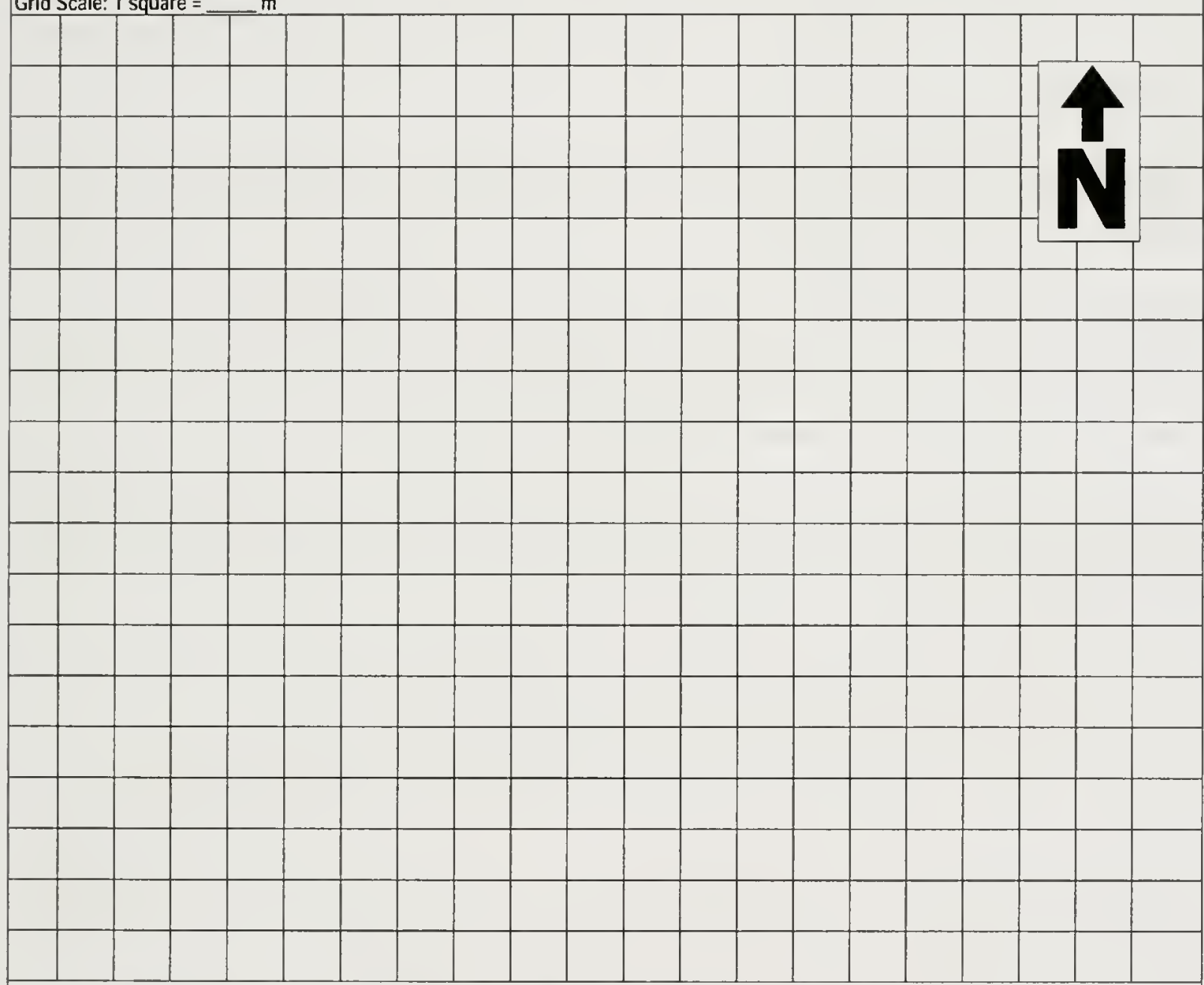

- Note all photo locations and directions What is the overall size of the wetland? 
3.0 Hydrogeomorphology Condition

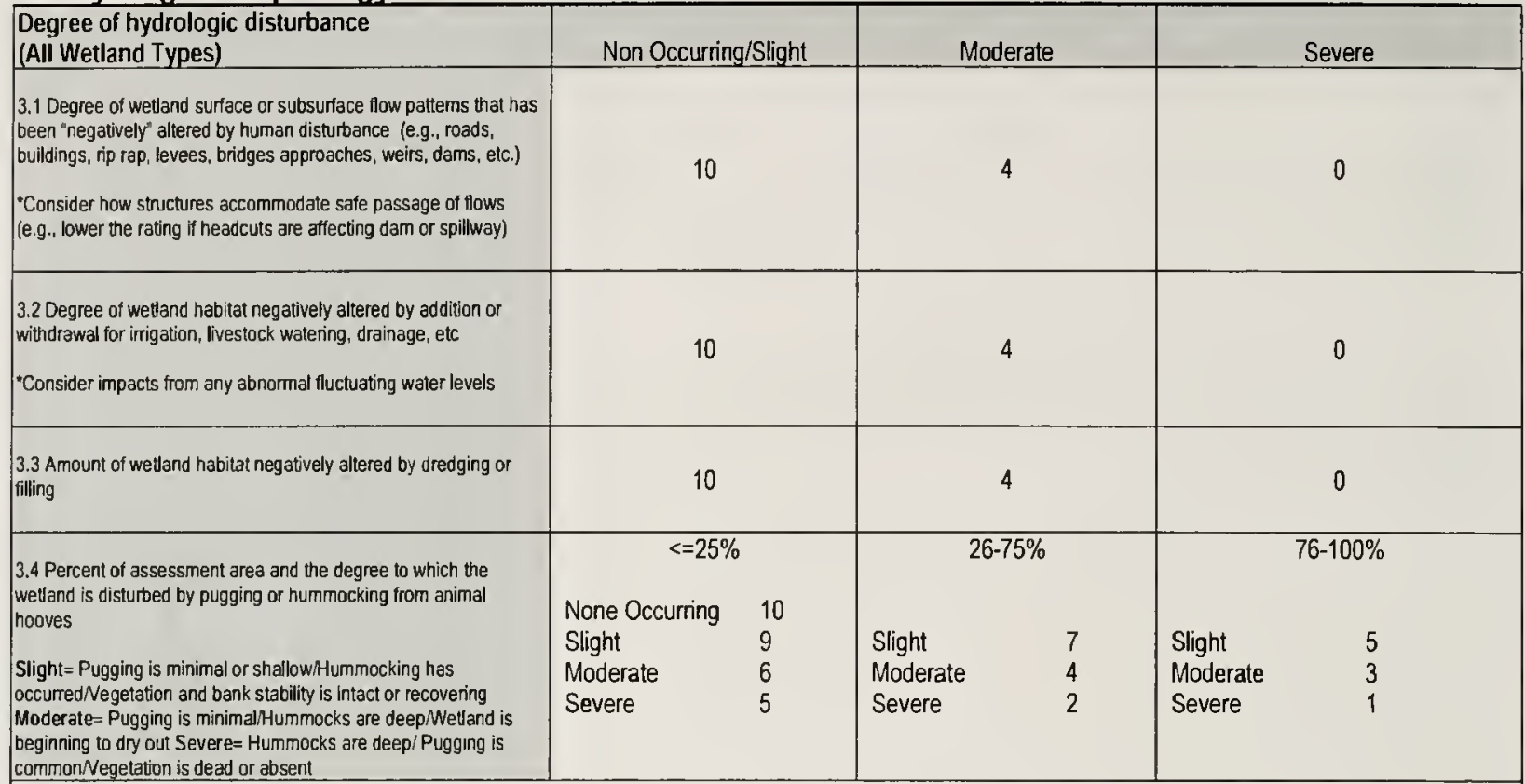

\section{Hydrogeomorphic Condition Index}

For hydrologic disturbance take the sum of the lowest 2 scores $(3.1-3.4)$ and divide by 20 :

$$
+120=(
$$

*Riverine Index

"For Riverine Sites use average of Riverine and Hydrogeomorphology Indexes.

Please provide comments for any impacts that scores $<5$ : 
Hydrogeomorphology - Riverine Wetland Addendum (Include only for Riverine Wetlands)

The aclualscore reflects current condition, and the polentialis the score that reflects the site without human disturbance (usually the maximum score).

3.5 Riverine - Downcutting/lncisement: Note: The presence of active headcuts should nearly always keep the stream reach from being rated sustainable.

Stable Channel

Evidence of downcutting that is beginning to stabilize

Sinall headcuts; channel is in beginning staged of unraveling.

Unstable channel that is incised and actovely widening, banks failure is common

Deeply incised resembling a gully

3.6 Riverine - Percent of Stream banks with active Lateral cutting:

Lateral bank erosion is in balance with the stream and its setting

There is a minımal amount af human-induced, active lateral bank erosion occuming, primanily limited to outside banks.

There is a moderate amount of human-induced active lateral bank erosion on either or both outside or inside banks

There is extensive human-induced lateral bank erosion occumng on outside and inside banks and straight sections.

3.7 Riverine - Stream in Balance with Water and Sediment Supply: Note: Rosgen B and naturally occuming D channels are exceptions.

No evidence of excessive sediment removal or deposition, or that the stream is getting wider.

The stream has widened and/or become shallower due to unstable banks or from de-watering. New point bars are often forming with silt and sand common

The stream tends to be very wide and shallow. Mid channel bars are often present. (See guidebook for praines streams characteristics)

The stream has poor sediment tansport. The channel is otten braided with at least 3 active channels

3.8 Riverine - Floodplain Characterization: (Rosgen diagrams are available in (he handbook)

Litte evidence of floodplain erosion

Floodplain erosion not extensive

Considerable evidence of floodplain erosion and occasional headcuts

Erosion and headcuts within the floodplain are extensive. Some human-caused stream bank erosion is occuming

The floodplain is very limited or does not exist

3.9 Riverine - Streambank with Vegetation (Kind) having a Deep, Binding Rootmass: (see Appendix for stability ratings for mosi riparian, and other, species)

The streambank vegetative communities are comprised of at least four plant species with deep binding root masses

The streambank vegetative communities are comprised of at least three plant species with deep binding root masses

The streambank vegetative communities are comprised of at least two plant species with deep binding root masses

The streambank vegetative communities are comprised of one or no plant species with deep binding root masses

3.10 Riverine - Streambank with Vegetation (Amount) having a Deep, Binding Rootmass: (see Appendix for stability ratings for most riparian, and other, species)

More than $85 \%$ of the floodplain has vegetation with a stability rating greater than or equal to 6

75. $85 \%$ of the floodplain has vegetation with a stability rating greater than or equal to 6

$65-75 \%$ of the floodplain has vegetation with a stability ratung greater than or equal to 6

$<65 \%$ of the floodplain has vegetation with a stability rating greater than or equad to 6

Please provide comment for any individual score $<6$ :

\begin{tabular}{|l|l|}
\hline & \\
\hline & \\
\hline & \\
\hline & \\
\hline & \\
\hline
\end{tabular}


4.0 Vegetation Condition Vegetation should only be assessed within the wetland assessment area

\begin{tabular}{|l|c|c|c|c|}
\hline 4.1 Bare Ground & $\begin{array}{c}\text { None present Minimal } \\
<=5 \%\end{array}$ & $\begin{array}{c}\text { Some Present } \\
6-15 \%\end{array}$ & $\begin{array}{c}\text { Common Occurrence } \\
16-25 \%\end{array}$ & $\begin{array}{c}\text { Very apparent } \\
25 \%\end{array}$ \\
\hline $\begin{array}{l}\text { How much emergent vegetation is } \\
\text { impacted by trampling or other } \\
\text { human-caused disturbance? }\end{array}$ & 10 & 8 & 4 & 0 \\
\hline
\end{tabular}

human-caused distumance?

*For Noxious and Disturbance Caused Undesirable plants, look to the abundance of harmful species.

\begin{tabular}{|c|c|c|c|c|c|}
\hline \multicolumn{2}{|c|}{$\begin{array}{l}4.2 \text { Invasive and Disturbance caused } \\
\text { undesirable plants } \\
\text { (Rank } 3 \text { most common and check all other } \\
\text { observations) }\end{array}$} & None present & $\begin{array}{l}\text { Some small patches are } \\
\text { often present } \\
\qquad<=5 \%\end{array}$ & $\begin{array}{l}\text { Patches are large or } \\
\text { commonly present } \\
6-25 \%\end{array}$ & $\begin{array}{l}\text { Patches are large and } \\
\text { extensive or Wetland is } \\
\text { Dominated } \\
\qquad>25 \%\end{array}$ \\
\hline $\begin{array}{l}\text { Reed Canary grass } \\
\text { Smooth brome } \\
\text { Ouack grass } \\
\text { Kentuchy bluegrass } \\
\text { Creeping Bent grass }\end{array}$ & $\begin{array}{l}\text { Meadow Foxtail } \\
\text { Tall Fescua } \\
\text { Timothy } \\
\text { Sweet Clover } \\
\text { Russian Olive }\end{array}$ & 10 & 7 & 5 & 2 \\
\hline \multicolumn{2}{|c|}{$\begin{array}{l}4.3 \text { Noxious Weeds } \\
\text { (Rank } 3 \text { most common and check all other } \\
\text { observations) }\end{array}$} & None present & $\begin{array}{l}\text { Some small patches are } \\
\text { often present } \\
\qquad<=5 \%\end{array}$ & $\begin{array}{l}\text { Patches are large or } \\
\text { commonly present } \\
6-25 \%\end{array}$ & $\begin{array}{l}\text { Patches are large and } \\
\text { extensive or Wetland is } \\
\text { Dominated } \\
\qquad>25 \%\end{array}$ \\
\hline $\begin{array}{l}\text { _Tamarisk (Sakt Cedar) } \\
\text { Canada Thistle } \\
\text { White Top Cress } \\
\text { Spotted Knapweed }\end{array}$ & $\begin{array}{l}\text { Leafy Spurge } \\
\text { _-Purple Loosestrife } \\
\text { _Yellowllag Ins } \\
\text { _Eurasian Mitfoil }\end{array}$ & 10 & 6 & 3 & 0 \\
\hline
\end{tabular}

Is woody vegetation present? Yes__ No___ Skip the rest of this section if the site does not have the potential for tall shrubs or trees or woody vegetation is not present due to natural causes (not human impacts or removal).

\begin{tabular}{|c|c|c|c|c|c|c|}
\hline \multicolumn{5}{|l|}{ 4.4 Woody Species Establishment and Regeneration } & Actual & Potential \\
\hline \multicolumn{5}{|l|}{ All age classes of desirable woody species present (see Guidebook). } & 10 & 10 \\
\hline \multicolumn{5}{|c|}{ One age class of desirable woody species is clearly absent, all others well represented. Often, it will be the middle age group (s) absent } & 6 & 6 \\
\hline \multicolumn{5}{|c|}{$\begin{array}{l}\text { Two age classes (seedlings and saplings) of native shrubs and/or two age classes of native trees are clearly absent, or the stand is comprised of } \\
\text { mainly mature species. Other age classes well represented. }\end{array}$} & 4 & 4 \\
\hline \multicolumn{5}{|c|}{$\begin{array}{l}\text { Disturbance induced, (i.e., facultative, facultative upland species such as rose, or snowberry) or non-wetands dominate. Woody species present } \\
\text { consist of decadentdying individuals }\end{array}$} & 2 & 2 \\
\hline \multicolumn{5}{|c|}{$\begin{array}{l}\text { A few woody species are presenl (<10\% canopy cover), but herbaceous species dominate (at this point, the site potential should be re-evaluated to } \\
\text { ensure that it has potential for woody vegetation). OR, the sile has at } \geq 5 \% \text { canopy cover of Russian olive and/or salt cedar. }\end{array}$} & 0 & 0 \\
\hline \multicolumn{5}{|c|}{4.5 Utilization of trees and shrubs: } & Actual & Potential \\
\hline \multicolumn{5}{|l|}{ Few to none of the available second year and older stems are browsed } & 10 & 10 \\
\hline \multicolumn{5}{|l|}{ Second year and older stems lightly browsed } & 8 & 8 \\
\hline \multicolumn{5}{|l|}{ Second year and older stems are moderately browsed. } & 6 & 6 \\
\hline \multicolumn{5}{|c|}{ Second year and older stems are heavily browsed. Many of the shrubs have either a "clubbed" growth form, or they are high-lined or umbrella shaped. } & 2 & 2 \\
\hline \multicolumn{5}{|c|}{ There is noticeable use (10\% or more) of unpalatable and normally unused woody species } & 0 & 0 \\
\hline \multirow{2}{*}{$\begin{array}{l}\text { 4.6 Percent of physical removal of tree/shrub layer or } \\
\text { dead wood caused by concentrated livestock trampling and rubbing, } \\
\text { drying out of site due to stream incisement, human-caused wetland } \\
\text { drainage or flooding, etc. }\end{array}$} & $<=5 \%$ & $6-25 \%$ & $26-50 \%$ & $51.75 \%$ & \multicolumn{2}{|r|}{$76-100 \%$} \\
\hline & 10 & 8 & 5 & 2 & \multicolumn{2}{|r|}{0} \\
\hline \multicolumn{7}{|l|}{ Please provide comments for any individual scores less than 6 : } \\
\hline \multicolumn{7}{|l|}{ If Potential is not at maximum, please explain: } \\
\hline \multicolumn{7}{|c|}{$\begin{array}{l}\text { Vegetation Condition Index } \\
\text { Sum all scores and divide by the total possible for the assessment area. } 60 \text { for sites with woody species (shrubs and tree); } 30 \text { for sites with anly herbaceous } \\
\text { vegetation). } \\
\text { Only Herbaceous (4.1-4.3): } \\
\text { For Herbaceous and woody vegetation (4.1-4.6): } \\
(110+\quad / 10+\quad / 10+\text { actual/potential + actual/potential }+\quad 110) / 6=\end{array}$} \\
\hline
\end{tabular}


5.0 Water Quality: Is water present? Yes

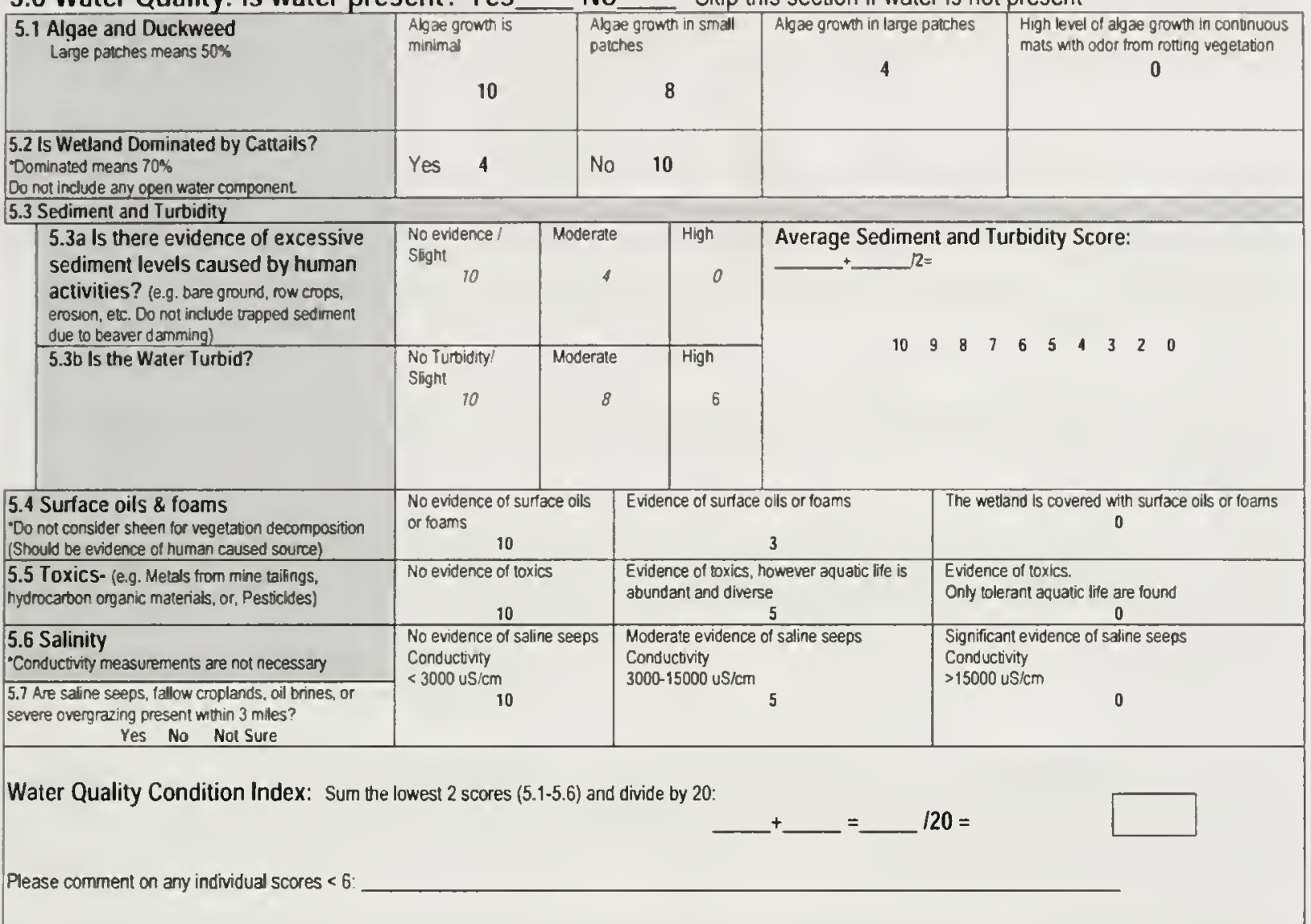

6.0 Buffer Condition/ Degree of Stress

\begin{tabular}{|c|c|c|c|c|}
\hline Stressors in 100 meter buffer & $\begin{array}{l}\text { None present } \\
\text { Very few present } \\
\text { Minimal } \\
\text { Small Patches } \\
\end{array}$ & $\begin{array}{l}\text { Common } \\
\text { Occurrence } \\
\text { Large patches within } \\
\text { Buffer }\end{array}$ & $\begin{array}{l}\text { Very apparent and ex } \\
\text { Distribution } \\
\text { Extensive Large Patc }\end{array}$ & ut entire Buffer \\
\hline 6.1 Amount of bare ground & 10 & \begin{tabular}{ll}
\multicolumn{2}{c}{ Slope } \\
Flat & 6 \\
Moderate & 4 \\
Steep & 3 \\
\end{tabular} & $\begin{array}{l}\quad \text { Slope } \\
\text { Flat } \\
\text { Moderate } \\
\text { Steep }\end{array}$ & \multirow{6}{*}{$\begin{array}{l}\text { Slope } \\
\text { Flat }=<2 \text { percent grade }\end{array}$} \\
\hline $\begin{array}{l}\text { 6. } 2 \text { Noxious weeds } \\
\text { (Use Montana Noxious Weed Pamphlet) }\end{array}$ & 10 & 2 & 0 & \\
\hline $\begin{array}{l}\text { 6.3 Disturbance- caused undesirable } \\
\text { plants }\end{array}$ & 10 & 4 & 0 & \\
\hline Degree of Stress in Buffer & $\begin{array}{c}\text { None } \\
\text { Occuming/Slight }\end{array}$ & Moderate & Severe & \\
\hline $\begin{array}{l}6.4 \text { Grazing intensity } \\
\text { in } 100 \text { meter buffer }\end{array}$ & 10 & \begin{tabular}{ll}
\multicolumn{1}{c}{ Slope } \\
Flat & 7 \\
Moderate & 5 \\
Sleep & 4 \\
\end{tabular} & $\begin{array}{l}\quad \text { Slope } \\
\text { Flat } \\
\text { Moderate } \\
\text { Steep }\end{array}$ & \\
\hline $\begin{array}{l}6.5 \text { Recreational Activities (e.g. } \\
\text { campground, fishing access point, } \\
\text { etc.) }\end{array}$ & 10 & \begin{tabular}{ll}
\multicolumn{2}{c}{ Slope } \\
Flat & 7 \\
Moderate & 5 \\
Steep & 4 \\
\end{tabular} & \begin{tabular}{l}
\multicolumn{1}{c}{ Slope } \\
Flat \\
Moderate \\
Steep
\end{tabular} & \\
\hline
\end{tabular}




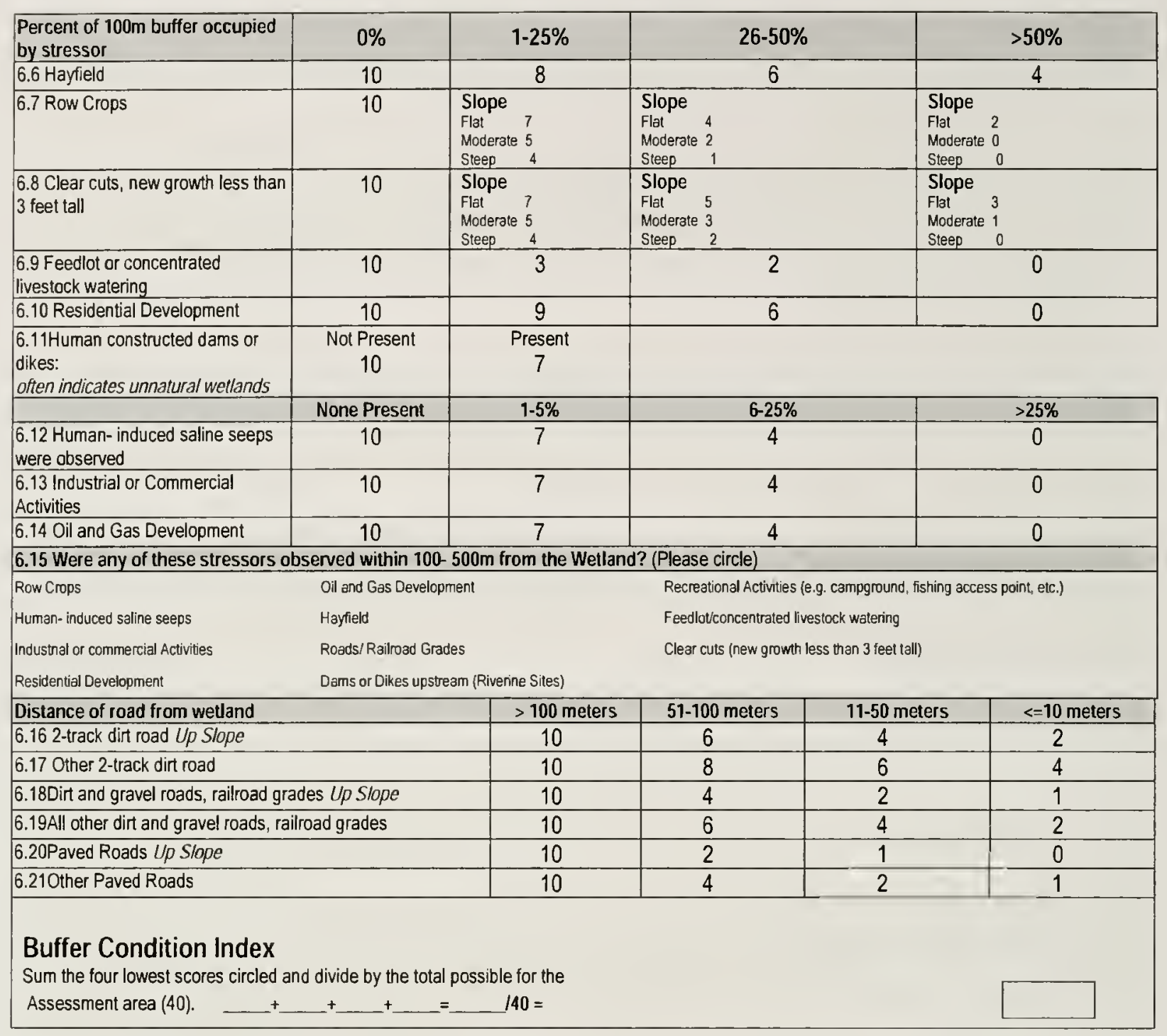

7.0 Restorability Circle the appropriate category and sub-category and describe how the wetland is trending (when appropriate)

\begin{tabular}{|c|c|c|c|c|}
\hline $\begin{array}{l}7.7 \text { How } \\
\text { easily can } \\
\text { the wetland } \\
\text { be restored? }\end{array}$ & $\begin{array}{l}\text { Category A: } \\
\text { No observed impacts; } \\
\text { Wetland does not need } \\
\text { to be restored. }\end{array}$ & $\begin{array}{l}\text { Category B: } \\
\text { Some slight impacts that } \\
\text { can be fixed or restored } \\
\text { with minimal expense } \\
\text { and effort (e.g. adding } \\
\text { fencing). }\end{array}$ & $\begin{array}{l}\text { Category C } \\
\text { More significant impacts or disturbances } \\
\text { within the buffer area that can be removed. } \\
\text { (such as a change in land use practices: } \\
\text { e.g. crop land changed to pasture, cattle } \\
\text { tank or abundant noxious weeds) } \\
\text { Restoration would require some expense } \\
\text { and effort. }\end{array}$ & $\begin{array}{l}\text { Category } D \text { : } \\
\text { Serious impacts and stressors } \\
\text { are not economically feasible to } \\
\text { remove/restore. (e.g., highway or } \\
\text { fixed permanent infrastructure) }\end{array}$ \\
\hline $\begin{array}{l}7.2 \text { Wetland } \\
\text { Trend } \\
\text { towards } \\
\text { natural } \\
\text { restoration } \\
\end{array}$ & $\begin{array}{l}\text { Sub-Category } 1 \text { : } \\
\text { Wetland condition is } \\
\text { trending upward. }\end{array}$ & $\begin{array}{l}\text { Sub-Category 2: } \\
\text { Wetland condition } \\
\text { appears to be stable. }\end{array}$ & $\begin{array}{l}\text { Sub Category } 3 \text { : } \\
\text { Wetland condition is trending downward. }\end{array}$ & $\begin{array}{l}\text { Sub-Category 4: } \\
\text { Wetland condition trend can not } \\
\text { be determined }\end{array}$ \\
\hline \multicolumn{5}{|l|}{ Comments: } \\
\hline
\end{tabular}




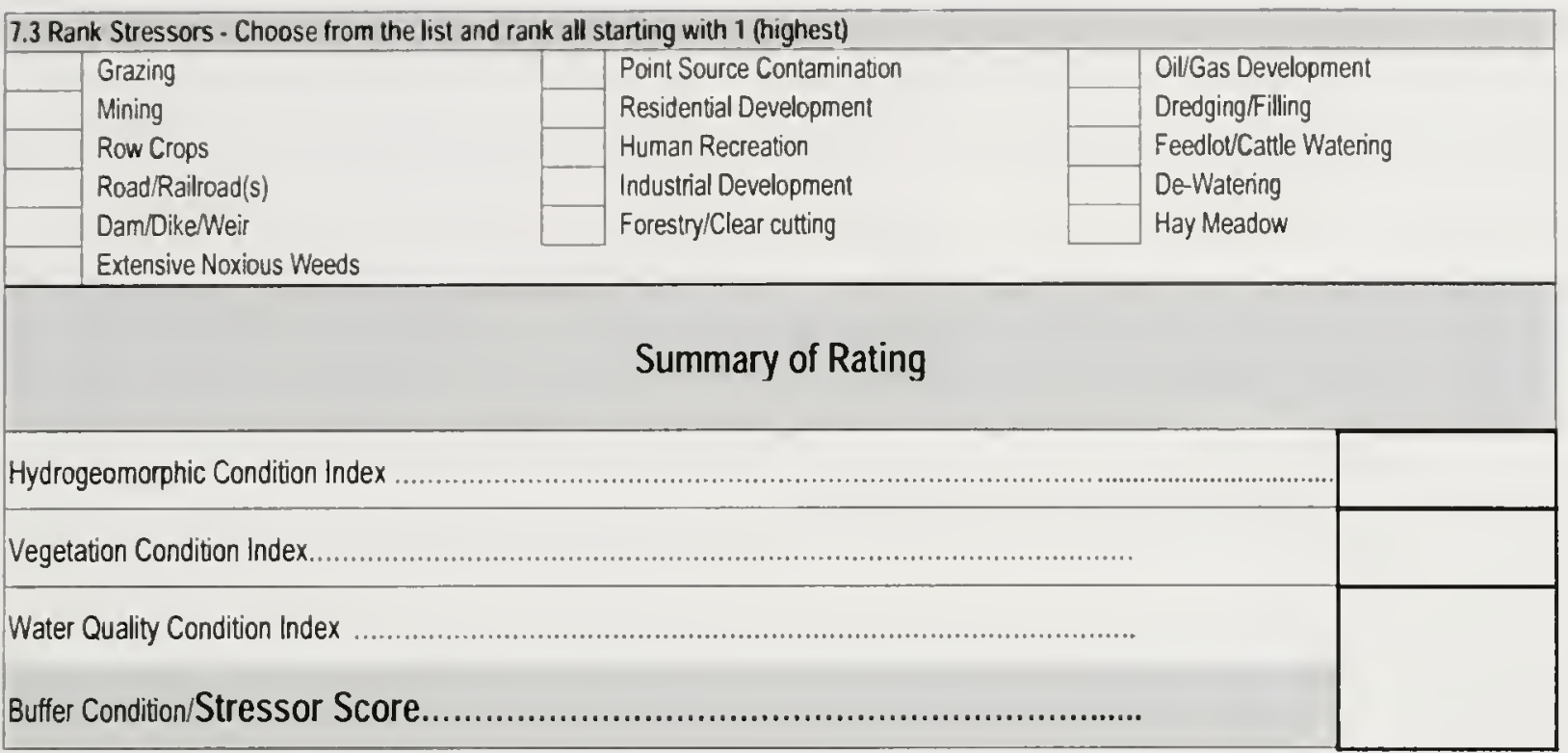

\section{Wetland Impact Score Calculation:}

If there is surface water multiply the hydrogeomorphic condition index by 0.4 ; the vegetation condition index by 0.4 ; the water quality condition index by 0.2 .

If there is no surface water multiply the hydrogeomorphic condition index by 0.5 ; the vegetation condition index by 0.5 .

\section{Wetland Impact Score}

\section{Overall Score calculations:}

If there is surface water multiply the hydrogeomorphic condition index by 0.3 ; the vegetation condition index by 0.3 ; the water condition index by 0.2 ; and the buffer condition/ Stressor index by 0.2 . Sum the indexes to determine the overall condition index score.

If there is no surface water multiply the hydrogeomorphic condition index by 0.4 ; the vegetation condition index by 0.4 ; the buffer condition/ Stressor index by 0.2 ; Sum the indexes to determine the overall condition index score.

\section{Overall Score}

- This score is not an indication of wetland impaiment status. This form is used to record observations only. The form can be submitted to Department of Environmental Quality for professional review to assist in evaluating wetland condition.

Overall condition index >0.9-1.0: Excellent Condition

Overall condition index $>0.5-0.7$ : Fair condition

Overall condition index >0.7-0.9: Good Condition

Overall condition index $\quad 0.0-0.5$ : Poor Condition 


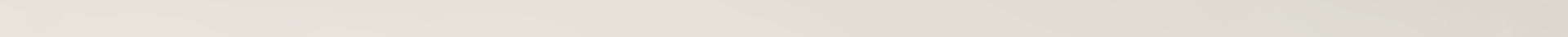

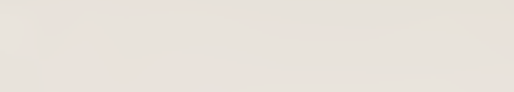

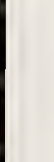

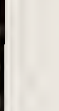

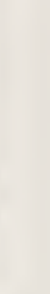

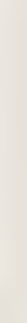

.
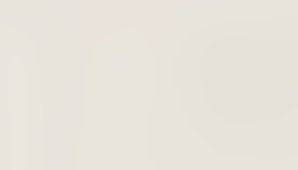
Appendix B. Development of the Montana Landscape INTEGRITY MODEL 


\section{.}

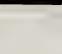

(1)

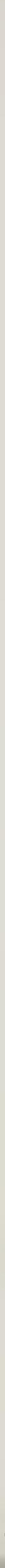


The Montana Landscape Integrity Model is designed to identify areas of the state where human activities have changed the landscape in ways that are broadly assumed to affect wetland condition by altering chemical, hydrologic, physical, or biotic properties. It uses four categories of change: roads, land cover, hydrology, and resource extraction. Each category has several components. For example, roads are divided into four-wheel drive roads, local roads and highways; land cover is broken into urban surfaces, agricultural lands, and timber harvest areas ${ }^{\prime}$, and so on.

In ArcGIS, we created an inverse distance raster layer for each landscape component, using a Euclidean distance function. This resulted in a statewide data file for each component, in which each 30 meter by 30 meter pixel ( 900 square meters) had a value that represents its distance, in meters, from the change component. We then reclassified the data into interval "scores," based on buffer distances. Pixels within 100 meters of a highway were given a score of 5, for example, while pixels more than 500 meters away were given a score of 1 . For large-scale impacts, like developed urban areas, the size of each buffer was extended; to receive a score of 1 , a pixel had to be at least 2000 meters from any land cover classified as "developed, medium intensity." The assumptions underlying each score assignment were based on the earlier data analysis, the literature, best professional judgment, or a combination of all three. For example, while we assumed that the impacts of highways would extend as far as 500 meters, we surmised that the impacts of four-wheel drive roads would occur at less of a distance, so that data layer was reclassified into only three levels (based on distances of 0-100 meters, 100-200 meters, and greater than 200 meters). Table B-1 shows each category, its components, and the scores assigned to each buffer distance.

Once buffer distances were reclassified, individual components were weighted and summed into overall category rasters (e.g. weighted roads, weighted landcover, etc) using the weighted sum function. These four category layers were then weighted again, and combined into a final Landscape Integrity Model. The road and land cover categories were each given $35 \%$ of the final total, the hydrology layer was given $20 \%$, and the resource extraction category was given a weight of $10 \%$. Final values for each pixel in the Landscape lntegrity Model ranged from 100 to 745 . We did not reclassify those values further for this study, but it could easily be done to give it a more familiar scale (e.g. 1 to 10). In this case, we would also reverse the values so that high scores represented areas of greater integrity and low scores represented areas of higher integrity.

As is always the case, the model is only as good as the data that goes into it. None of the data layers we used in the model is current and complete. The roads layer captures section roads in eastern Montana which are rarely if ever used while omitting unofficial but heavily used twotracks, and all the roads that have been added since the last census. The land cover layer, while

\footnotetext{
1 Timber harvest areas were identified from the Montana Cadastral Layer. We selected lands owned by the large. active timber companies: Plum Creek, Stimson, and Stolze, and turned these into a raster layer. Although timber harvest certainly occurs on smaller holdings, we had no way of identifying those parcels. Although the cadastral layer shows lands taxed as timber land, it does not indicate what land is being actively cut. When the Pacific Northwest ReGAP maps are complete, it should be possible to refine a timber harvest area.

2 We did not use the NLCD classes "Developed, low intensity" or "Developed, high intensity" in the final iteration. Low intensity development had no significant relationship to wetland condition in our initial analysis. The NLCD class "Developed. high intensity" is primarily a road layer in Montana, and was therefore redundant.
} 
drawn from the $2001 \mathrm{NLCD}$, is based on satellite imagery from the 1990s. The water rights point of use data contains both georectified data with specific $\mathrm{x}, \mathrm{y}$ coordinates and points dropped into the center of a public land survey section because no more precise data was available. The energy layer was current through the summer of 2008, but is probably out of date now. The abandoned mines data was a point layer, and did not necessarily reflect the extent of mining impacts. And some layers were not available at all. The absence of statewide NWI coverage meant that we could not build a distance layer from altered wetlands, even though the density of these wetlands within a given subwatershed is probably a very good indicator of overall wetland condition.

Table B-I. Scoring and weighting of landscape-level impacts.

\section{Category}

\section{Roads}

4-wheel drive (15\%)

Highways (50\%)

\section{Land Cover}

Urban (40\%)

Crop agriculture (40\%)

Timber harvest (20\%)

\section{Buffer distance (meters)}

$0-100$

100.01-200

$>200.01$

Local roads, city streets $(35 \%)$

$0-100$

100.01-200

200.01-300

$>300.01$

$0-100$

100.01-200

200.01-300

$300-500$

$>500.01$

$0-500$

$500.01-1000$

$1000.01-1500$

$1500.01-2000$

$>2000.01$

$0-200$

200.01-300

$300.01-400$

400.01-500

$>500$

$0-500$

$500.01-1000$

$1000.01-1500$

1500.01-2000

$>2000.01$

\section{Score}

Weight

$35 \%$

3

2

1

4

3

2

1

5

4

3

2

1

$35 \%$ 


$\begin{array}{lllc}\text { Category } & \begin{array}{l}\text { Buffer distance } \\ \text { (meters) }\end{array} & \text { Score } & \text { Weight } \\ \text { Hydrology } & 0-100 & 3 & 20 \% \\ \text { Artificial flow (25\%) } & 100.01-200 & 2 & \\ & >200.01 & 3 & 10 \% \\ \text { Water right point of use (50\%) } & 0-100 & 2 \\ & 100.01-200 & 1 \\ \text { Section 404 permit (25\%) } & >200.01 & 3 \\ & 0-100 & 2 \\ \text { Resource extraction } & 100.01-200 & 1 \\ \text { Abandoned mines }(50 \%) & >200.01 & 5 \\ & 0-100 & 4 \\ & 100.01-200 & 3 \\ & 200.01-300 & 2 \\ \text { Oil or gas extraction }(50 \%) & 300.01-500 & 1 \\ & >500.01 & 5 \\ & 0-100 & 4 \\ & 100.01-200 & 3 \\ & 200.01-300 & 2 \\ & 300.01-500 & 1 \\ & >500.01 & & \end{array}$



Appendix C. Ecological Integrity Assessment Form 

SITE NAME

SITE ID:

ASSESSMENT AREA SIZE IN $\mathrm{M}^{2}$

OWNERSHIP

HUC4:

HUC5

ELEVATION

GPS WAYPOINT

Datum
Lat:
Long:
(Use decimal degrees)

(Use decimal degrees)

General site description, including surrounding uplands
DATE OF VISIT:

ASSESSED BY:

PROJECT/PURPOSE

Stream order, if riverine

Fish sampled?

Macroinvertebrates sampled?

Sample ID, if yes

\section{Directions to site:}

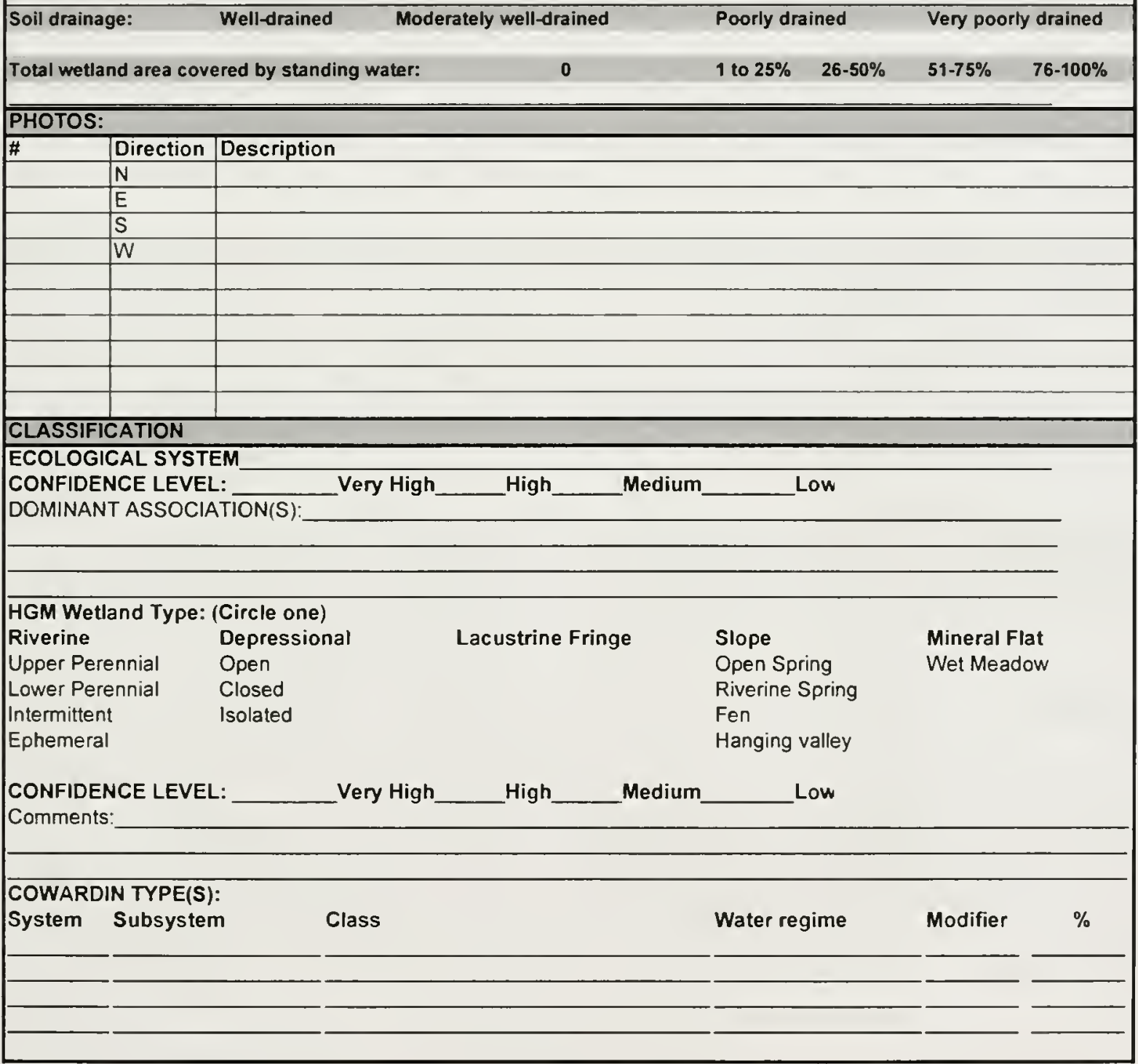


Site Name

LEVEL II ASSESSMENT-Marshes, wet meadows, potholes

\begin{tabular}{|c|c|c|c|c|c|}
\hline METRIC & EXCELLENT(A) & GOOD(B) & FAIR (C) & POOR(D) & SCORE \\
\hline \multicolumn{6}{|l|}{ LANDSCAPE CONTEXT } \\
\hline \multicolumn{6}{|l|}{ Connectivity } \\
\hline Non-riverine & $\begin{array}{l}90-100 \% \text { natural habitat } \\
\text { within } 500 \mathrm{~m} \text { of wetland } \\
\text { perimeter }\end{array}$ & $\begin{array}{l}60-90 \% \text { natural habitat } \\
\text { within } 500 \mathrm{~m} \text { of wetland } \\
\text { penmeler }\end{array}$ & $\begin{array}{l}10-60 \% \text { natural habitat } \\
\text { within } 500 \mathrm{~m} \text { of wetland } \\
\text { perimeter }\end{array}$ & $\begin{array}{l}<10 \% \text { natural habitat within } \\
500 \mathrm{~m} \text { of wetland perimeter }\end{array}$ & \\
\hline Riverine & $\begin{array}{l}90-100 \% \text { nalural habitat } \\
\text { within } 500 \mathrm{~m} \text { on either } \\
\text { side and } 500 \mathrm{~m} \\
\text { upstream and } \\
\text { downstream }\end{array}$ & $\begin{array}{l}60-90 \% \text { natural habitat } \\
\text { within } 500 \mathrm{~m} \text { on either } \\
\text { side and } 500 \mathrm{~m} \text { upstream } \\
\text { and downstream }\end{array}$ & $\begin{array}{l}10-60 \% \text { natural habitat } \\
\text { within } 500 \mathrm{~m} \text { on either } \\
\text { side and } 500 \mathrm{~m} \text { upstream } \\
\text { and downstream }\end{array}$ & $\begin{array}{l}<10 \% \text { natural habitat within } \\
500 \mathrm{~m} \text { on either side and } 500 \\
m \text { upstream and downstream }\end{array}$ & \\
\hline \multicolumn{6}{|l|}{ Buffer } \\
\hline Length & $\begin{array}{l}\text { Buffer is }>75 \% \text { of } \\
\text { wetland perimeter }\end{array}$ & $\begin{array}{l}\text { Buffer is } 50-75 \% \text { of } \\
\text { wetland penmeter }\end{array}$ & $\begin{array}{l}\text { Buffer is } 25-50 \% \text { of } \\
\text { wetland perimeter }\end{array}$ & $\begin{array}{l}\text { Buffer is }<25 \% \text { of wetland } \\
\text { perimeter }\end{array}$ & \\
\hline Width & $\begin{array}{l}\text { Average buffer width is } \\
>200 \mathrm{~m} \text {, adjusted for } \\
\text { slope }\end{array}$ & $\begin{array}{l}\text { Average buffer width } 100- \\
200 \mathrm{~m} \text {, adjusted for slope }\end{array}$ & $\begin{array}{l}\text { Average buffer width is } 50 \\
100 \mathrm{~m} \text {, adjusted for slope }\end{array}$ & $\begin{array}{l}\text { Average buffer width is }<50 \\
\mathrm{~m} \text {, adjusted for slope }\end{array}$ & \\
\hline Condition & $\begin{array}{l}\text { Buffer is }>95 \% \text { native } \\
\text { vegelation with intact } \\
\text { soils and little or no } \\
\text { trash or refuse }\end{array}$ & $\begin{array}{l}\text { Buffer is }>75-95 \% \text { native } \\
\text { vegelation with intact or } \\
\text { slightly distrubed soils, } \\
\text { and minor evidence of } \\
\text { human visitation or } \\
\text { recreation }\end{array}$ & $\begin{array}{l}\text { Buffer is }>25-75 \% \text { native } \\
\text { vegetation with slightly } 10 \\
\text { moderately distrubed } \\
\text { soils, and moderate } \\
\text { human visitation or } \\
\text { recreation }\end{array}$ & $\begin{array}{l}\text { Buffer is }<25 \% \text { native } \\
\text { vegetation with severely } \\
\text { disturbed soils, and } \\
\text { substantial human vitation or } \\
\text { recreation }\end{array}$ & \\
\hline \multicolumn{6}{|l|}{ SIZE } \\
\hline Relative Patch Size & $\begin{array}{l}\text { Wetland is }>95 \% \text { of } \\
\text { original size }\end{array}$ & $\begin{array}{l}\text { Wetland is } 80-95 \% \text { of } \\
\text { original size }\end{array}$ & $\begin{array}{l}\text { Wetland is } 50-80 \% \text { of } \\
\text { original size }\end{array}$ & $\begin{array}{l}\text { Wetland is }<50 \% \text { of original } \\
\text { size }\end{array}$ & \\
\hline Absolute Patch Size & $\begin{array}{l}\text { Welland is very large } \\
\text { compared to others of } \\
\text { its type (e.g, top } 10 \% \text { ) }\end{array}$ & $\begin{array}{l}\text { Welland is large } \\
\text { compared to others of its } \\
\text { type (e.g., top 10-30\%) }\end{array}$ & $\begin{array}{l}\text { Wetland is average } \\
\text { compared to others of its } \\
\text { type (e.g., } 30-70 \%)\end{array}$ & $\begin{array}{l}\text { Welland is too small to } \\
\text { sustain full function and } \\
\text { diversity }\end{array}$ & \\
\hline \multicolumn{6}{|c|}{ VEGETATION STRUCTURE (BIOTA) } \\
\hline Structure & \multicolumn{2}{|c|}{$\begin{array}{l}\text { Vegetation at or near reference standard } \\
\text { condition in structural proportions }\end{array}$} & $\begin{array}{l}\text { Vegetation moderately } \\
\text { altered from reference } \\
\text { standard condition in } \\
\text { structural proportions }\end{array}$ & $\begin{array}{l}\text { Vegetalion greatly altered } \\
\text { from reference standard } \\
\text { condition in structural } \\
\text { proportions } \\
\end{array}$ & \\
\hline Composition & \multicolumn{2}{|c|}{$\begin{array}{l}\text { Vegetation at or near reference standard } \\
\text { condition in species present and their } \\
\text { proportions. Regeneration good. Full suite of } \\
\text { diagnostic species present. }\end{array}$} & $\begin{array}{l}\text { Vegetation differs from } \\
\text { reference standard } \\
\text { condition but still largely } \\
\text { native. Tolerant or weedy } \\
\text { natives may be present. } \\
\text { Many indicators absent. }\end{array}$ & $\begin{array}{l}\text { Vegetation severely altered } \\
\text { from reference slandard. } \\
\text { Some strata absent or } \\
\text { dominated by weedy species. } \\
\text { Most indicator species absent. }\end{array}$ & \\
\hline $\begin{array}{l}\text { Relative Cover of } \\
\text { Native Plant Species }\end{array}$ & $\begin{array}{l}>99 \% \text { relative cover of } \\
\text { native plants }\end{array}$ & $\begin{array}{l}95-99 \% \text { relative cover of } \\
\text { native plants }\end{array}$ & $\begin{array}{l}80-94 \% \text { relative cover of } \\
\text { native plants }\end{array}$ & $\begin{array}{l}50-79 \% \text { relative cover of } \\
\text { nalive plants }\end{array}$ & \\
\hline Invasive exotic species & $\begin{array}{l}\text { No key invasive exotic } \\
\text { planls present }\end{array}$ & $\begin{array}{l}<3 \% \text { invasive exotic } \\
\text { plants presenl }\end{array}$ & $\begin{array}{l}3-5 \% \text { invasive exotic } \\
\text { plants present }\end{array}$ & $\begin{array}{l}>5 \% \text { invasive exotic plants } \\
\text { present }\end{array}$ & \\
\hline $\begin{array}{l}\text { Organic Matter } \\
\text { Accumulation }\end{array}$ & $\begin{array}{l}\text { Site has moderate amc } \\
\text { matter. New materials } \\
\text { old materials. Layers ir } \\
\text { lows are thin. }\end{array}$ & $\begin{array}{l}\text { mount of fine organic } \\
\text { more prevalent than } \\
\text { pools or topographic }\end{array}$ & $\begin{array}{l}\text { Site is characterized by } \\
\text { small amounts of coarse } \\
\text { organic debris, with little } \\
\text { organic matter } \\
\text { recuritmenl, OR debris is } \\
\text { somewha! excessive }\end{array}$ & $\begin{array}{l}\text { Sile has little coarse debris } \\
\text { and only scant fine debris OR } \\
\text { debris is excessive. }\end{array}$ & \\
\hline $\begin{array}{l}\text { Patch Types (See } \\
\text { below) }\end{array}$ & $\begin{array}{l}>7 \text { abiolic/biotic palch } \\
\text { types present in the } \\
\text { wetland ( }>6 \text { for } \\
\text { potholes) }\end{array}$ & $\begin{array}{l}5 \text { to } 7 \text { abiotic/biotic patch } \\
\text { types present in the } \\
\text { wetland (5 or } 6 \text { for } \\
\text { potholes) }\end{array}$ & $\begin{array}{l}3 \text { or } 4 \text { abiolic/biotic palch } \\
\text { types present in the } \\
\text { wetland }\end{array}$ & $\begin{array}{l}1 \text { or } 2 \text { abiolic/biotic patch } \\
\text { types present }\end{array}$ & \\
\hline Patch Interspersion & $\begin{array}{l}\text { Horizontal structure } \\
\text { consists of a very } \\
\text { complex array of nested } \\
\text { or interspersed irregular } \\
\text { biotıc/abiotic patches } \\
\text { with no single dominant } \\
\text { type. }\end{array}$ & $\begin{array}{l}\text { Horizontal structure } \\
\text { consists of a moderately } \\
\text { complex array of nested } \\
\text { or interspersed irregular } \\
\text { bioticlabiotic patches with } \\
\text { no single dominanl type }\end{array}$ & $\begin{array}{l}\text { Honizontal structure } \\
\text { consists of a simple array } \\
\text { of nested or interspersed } \\
\text { irregular biolic/abiotic } \\
\text { patches with no single } \\
\text { dominant type }\end{array}$ & $\begin{array}{l}\text { Honizontal structure consists } \\
\text { of one dominant patch type } \\
\text { with no interspersion }\end{array}$ & \\
\hline
\end{tabular}


Site Name

LEVEL II ASSESSMENT-Marshes, wet meadows, potholes

Site ID

\begin{tabular}{|c|c|c|c|c|c|}
\hline METRIC & EXCELLENT(A) & GOOD(B) & FAIR (C) & POOR(D) & SCORE \\
\hline \multicolumn{6}{|l|}{ HYDROLOGY } \\
\hline Water Source & $\begin{array}{l}\text { Water source is } \\
\text { precipitation, } \\
\text { groundwater, natural } \\
\text { runoff OR system } \\
\text { naturally lacks water } \\
\text { during growing season. } \\
\text { No indication of direct } \\
\text { artifical water source or } \\
\text { point source discharge }\end{array}$ & $\begin{array}{l}\text { Water source is mostly } \\
\text { natural, but site receives } \\
\text { occasional or small } \\
\text { amounts of inflow from } \\
\text { human sources e.g., road } \\
\text { runoff, storm drains, } \\
\text { imgation). No large point } \\
\text { source discharge into } \\
\text { site. }\end{array}$ & $\begin{array}{l}\text { Water source is pnmarily } \\
\text { runoff, imigation, pumped } \\
\text { water, impounded water. } \\
\text { or other artificial } \\
\text { hydrology Major point } \\
\text { sources discharging into } \\
\text { wetland may be present }\end{array}$ & $\begin{array}{l}\text { Water flow has been } \\
\text { substantially diminished by } \\
\text { Impoundments, diversions, or } \\
\text { withdrawals from wetland or } \\
\text { adjacent areas OR the water } \\
\text { source is so altered that } \\
\text { wetland vegetation is gone. }\end{array}$ & \\
\hline Hydroperiod & $\begin{array}{l}\text { Hydroperiod is } \\
\text { characterized by natural } \\
\text { periods of } \\
\text { filling/inundation and } \\
\text { drawing down. }\end{array}$ & $\begin{array}{l}\text { Filling or inundation is } \\
\text { greater and of greater or } \\
\text { lesser duration than } \\
\text { under natural conditions. } \\
\text { but the site is subject to } \\
\text { natural drying }\end{array}$ & $\begin{array}{l}\text { Filling or inundation is } \\
\text { natural, but drawdown } \\
\text { and drying more rapid, } \\
\text { OR filling/inundation is of } \\
\text { lower than natural } \\
\text { magnitude or duration, } \\
\text { but site is subject to } \\
\text { natural drying. }\end{array}$ & $\begin{array}{l}\text { Filling or inundation and } \\
\text { drawdown/drying both deviate } \\
\text { from natural regimes }\end{array}$ & \\
\hline $\begin{array}{l}\text { Hydrologic } \\
\text { Connectivity }\end{array}$ & $\begin{array}{l}\text { Rising water in the in } \\
\text { the site has unrestricted } \\
\text { access to adjacent } \\
\text { upland, without levees, } \\
\text { excessively high banks, } \\
\text { artificial bamers, or } \\
\text { other obstructions to } \\
\text { lateral movement of } \\
\text { flood flows. }\end{array}$ & $\begin{array}{l}\text { Rising water has partially } \\
\text { restricted }(<50 \%) \text { access } \\
\text { to upland due to } \\
\text { unnatural features OR } \\
\text { flood drainage back into } \\
\text { wetland is incomplete due } \\
\text { to impoundments or } \\
\text { bamiers }\end{array}$ & $\begin{array}{l}\text { Rising water has } \\
\text { significantly restricted ( } 50 \\
90 \% \text { ) access to upland } \\
\text { due to unnatural features }\end{array}$ & $\begin{array}{l}\text { All water stages in the wetland } \\
\text { are contained by artifical } \\
\text { banks, levees, walls, or berms } \\
\text { or }>90 \% \text { of wetland has } \\
\text { bamers to drainage. There is } \\
\text { essentially no hydrologic } \\
\text { connection to uplands. }\end{array}$ & \\
\hline \multicolumn{6}{|l|}{ PHYSIOCHEMICAL } \\
\hline Soil Surface Integrity & $\begin{array}{l}\text { Bare soil areas are } \\
\text { limited to naturally } \\
\text { caused disturbances } \\
\text { such as flood deposition } \\
\text { or game trails. }\end{array}$ & $\begin{array}{l}\text { Bare soil due to human } \\
\text { impacts is present but } \\
\text { minimal Water is not } \\
\text { ponding or channelled. }\end{array}$ & $\begin{array}{l}\text { Unnatural areas of bare } \\
\text { soil are common. Ponding } \\
\text { or channeling may be } \\
\text { present in shallow } \\
\text { disturbances }\end{array}$ & $\begin{array}{l}\text { Unnatural areas of bare soil } \\
\text { are extensive and ponding or } \\
\text { channeling is likely. Surface } \\
\text { disturbances are deep and } \\
\text { widespread. }\end{array}$ & \\
\hline Water Quality & $\begin{array}{l}\text { Water is clear with no } \\
\text { sheen, scum, or hint of } \\
\text { green. Plants that } \\
\text { respond to enrichment } \\
\text { are minimally present or } \\
\text { absent. }\end{array}$ & $\begin{array}{l}\text { Water has a minimal } \\
\text { greenish tint, cloudiness, } \\
\text { or sheen. Plants that } \\
\text { respond to enrichment } \\
\text { are present but not } \\
\text { dominant. }\end{array}$ & $\begin{array}{l}\text { Water has a moderate } \\
\text { greenish tint, sheen, or } \\
\text { turbidity with common } \\
\text { algae. Plants that } \\
\text { respond to enrichment } \\
\text { are common. }\end{array}$ & $\begin{array}{l}\text { Water has a strong greenish } \\
\text { tint, sheen, or turbidity } \\
\text { Surface algal mats or other } \\
\text { vegetation block light to the } \\
\text { bottom. }\end{array}$ & \\
\hline \multirow[t]{12}{*}{ Patch types: } & Freshwater marsh & Pothole & Wet Meadow & Playa & \\
\hline & Open water-stream & Open water & Open water-stream & Open water & \\
\hline & Oxbow/backwater & Shallow emergent & Oxbow/backwater & Mud flat & \\
\hline & Secondary channel & Saline meadow & Secondary channel & Salt flat & \\
\hline & Deep emergent plants & Hummocks or mounds & Deep emergent plants & Deep emergent plants & \\
\hline & Shallow emergent plants & Submerged or floating & Shallow emergent plants & Shallow emergent plants & \\
\hline & Beaver dam & Transitional meadow & Beaver dam & Saline meadows & \\
\hline & Trees & Tall emergent & Trees & Greasewood & \\
\hline & Shrubs & Shrubs & Shrubs & Seeps \& springs & \\
\hline & Springs/seeps & & Springs/seeps & Hummocks or mounds & \\
\hline & Submerged/floating veg & & Submerged/floating veg & Submerged or floating vegetation & \\
\hline & Transitional meadow & & Transitional meadow & Contributing stream & \\
\hline
\end{tabular}


Site Name

Site ID

\begin{tabular}{|c|c|}
\hline \multicolumn{2}{|l|}{ STRESSORS } \\
\hline Land use within $300 \mathrm{~m}$ of wetland edge & Percent land use \\
\hline \multicolumn{2}{|l|}{ Urban residential } \\
\hline \multicolumn{2}{|l|}{ Industrial/commercial } \\
\hline \multicolumn{2}{|l|}{ Military/airport } \\
\hline \multicolumn{2}{|l|}{ Dryland farming } \\
\hline \multicolumn{2}{|l|}{ Crop agriculture } \\
\hline \multicolumn{2}{|l|}{ Orchards/nurseries } \\
\hline \multicolumn{2}{|l|}{ Logging operation/timber removal } \\
\hline \multicolumn{2}{|l|}{ Feedlot } \\
\hline \multicolumn{2}{|l|}{ Dairy } \\
\hline \multicolumn{2}{|l|}{ Enclosed livestock grazing } \\
\hline \multicolumn{2}{|l|}{ Open range grazing } \\
\hline \multicolumn{2}{|l|}{ Sports field or park } \\
\hline \multicolumn{2}{|c|}{ Active recreation (OHV, mountain biking, shooting) } \\
\hline \multicolumn{2}{|l|}{ Resource extraction } \\
\hline \multicolumn{2}{|l|}{ Recent fire ( $<5$ years) } \\
\hline \multicolumn{2}{|l|}{ Boating (motorized) } \\
\hline Transportation with $500 \mathrm{~m}$ of wetland edge & Distance from edge \\
\hline \multicolumn{2}{|l|}{ Lightly travelled road } \\
\hline \multicolumn{2}{|l|}{ Moderately travelled road } \\
\hline \multicolumn{2}{|l|}{ Heavily travelled road } \\
\hline \multicolumn{2}{|l|}{ Pedestrian trail } \\
\hline Horse trail & \\
\hline Railroad & \\
\hline Land use within site & $\%$ of site \\
\hline Mowing & \\
\hline Livestock grazing & \\
\hline Excessive herbivory & \\
\hline Excessive human visitation & \\
\hline Tree cutting/sapling removal & \\
\hline Pesticide or herbicide application & \\
\hline Recent fire ( $<5$ years) & \\
\hline Recent flood & \\
\hline Invasive animals or plants & \\
\hline Hydrology within 300m & Impact (High/Medium/Low) \\
\hline Point source discharge & \\
\hline Non-point source discharge & \\
\hline Flow diversion or unnatural inflow & \\
\hline Dams & \\
\hline Flow obstructions & \\
\hline Weirs, headgates & \\
\hline Dredged inlet or channel & \\
\hline Engineered channel & \\
\hline Dike/levee & \\
\hline Groundwater pumping & \\
\hline Ditches & \\
\hline Soil disturbance witin $300 \mathrm{~m}$ & Impact (High/Medium/Low) \\
\hline Filling or dumping & \\
\hline Grading/compaction/roadwork & \\
\hline Plowing or discing & \\
\hline Logging or clearing & \\
\hline Unnatural areas of bare soil & \\
\hline Trash or refuse & \\
\hline Pugging, hummocking, or erosion & \\
\hline
\end{tabular}


